\section{Sedimentary}

\section{Research}

Journal of Sedimentary Research, 2008, v. 78, 480-498

Research Articles

DOI: $10.2110 /$ jsr.2008.052

\title{
DEPOSITS FROM WAVE-INFLUENCED TURBIDITY CURRENTS: PENNSYLVANIAN MINTURN FORMATION, COLORADO, U.S.A.
}

\author{
M.P. LAMB, ${ }^{1}$ P.M. MYROW, ${ }^{2}$ C. LUKENS, ${ }^{2}$ K. HOUCK, ${ }^{3}$ AND J. STRAUSS ${ }^{2}$ \\ ${ }^{1}$ Department of Earth \& Planetary Science, University of California, Berkeley, California 94720, U.S.A. \\ ${ }^{2}$ Department of Geology, Colorado College, Colorado Springs, Colorado 80903, U.S.A. \\ ${ }^{3}$ Department of Geography and Environmental Sciences, University of Colorado, Denver, Colorado, 80217-3363 U.S.A. \\ e-mail:mpl@berkeley.edu
}

\begin{abstract}
Turbidity currents generated nearshore have been suggested to be the source of some sandy marine event beds, but in most cases the evidence is circumstantial. Such flows must commonly travel through a field of oscillatory flow caused by wind-generated waves; little is known, however, about the interactions between waves and turbidity currents. We explore these interactions through detailed process-oriented sedimentological analysis of sandstone event beds from the Pennsylvanian Minturn Formation in north-central Colorado, U.S.A. The Minturn Formation exhibits a complex stratigraphic architecture of fan-delta deposits that developed in association with high topographic relief in a tectonically active setting. An $\sim 20-35-\mathrm{m}-$ thick, unconformity-bounded unit of prodelta deposits consists of dark green shale and turbidite-like sandstone beds with tool marks produced by abundant plant debris. Some of the sandstone event beds, most abundant at distal localities, contain reverseto-normal grading and sequences of sedimentary structures that indicate deposition from waxing to waning flows. In contrast, proximal deposits, in some cases less than a kilometer away, contain abundant beds with evidence for deposition by wavedominated combined flows, including large-scale hummocky cross-stratification. We interpret the majority of these event beds as a record of deposition from hyperpycnal flows, i.e., turbidity currents generated directly from highly concentrated river plumes, which accelerated and decelerated in response to a rising and falling flood discharge. Additional support for this interpretation includes the following: (1) a variety of sole marks including flute and gutter casts, as well as tool marks made by relatively large (up to tens of centimeters across) woody debris (i.e., groove, prod, and chevron marks); (2) consistent unimodal orientation of sole marks and abundant ripple cross-stratification, which indicate strong downslope-directed flow; (3) a well documented sedimentological framework for the formation of fan-delta deposits adjacent to nearby highlands; and (4) plant fossils typical of middle- to high-elevation habitats that are abundant in the turbidite beds but absent in underlying and overlying shoreline and marginal marine deposits, which have a separate floral assemblage. Differences in grain sizes, vertical stratification sequences, and bed thicknesses between outcrops are interpreted to result from the spatial distribution of wave effects, the time history of hyperpycnal flows, and the interaction of these processes. The latter varied both spatially and temporally and produced a wide range of bed types, which are incorporated into a new conceptual model for storm-influenced hyperpycnal flows.
\end{abstract}

\section{INTRODUCTION}

Mechanisms for the seaward transport of sediment from shoreline sources have been debated for more than twenty-five years. Cross-shelf transport of sediment was initially attributed to turbidity currents generated from sediment entrainment by storm-induced currents or from near-shore failures (Hamblin and Walker 1979; Wright and Walker 1982; Dott and Bourgeois 1982; Leckie and Walker 1982). This interpretation in part was due to the similarity of shallow marine event beds to deepwater turbidites with Bouma sequences and offshore-directed sole marks and bedforms. Oceanographic observations on continental shelves sparked debate, however, because storms were shown to form shoreparallel geostrophic flows (Swift et al. 1986; Duke et al. 1991), and it seemed unlikely that turbidity currents could maintain themselves over the low slopes typical of modern nearshore settings (Pantin 1979; Parker 1982; Swift 1985).
Recent studies, however, have reemphasized the importance of gravitydriven transport of sediment supplied to shelf environments by nearby rivers (e.g., Wright and Friedrichs 2006). Sediment-laden river plumes typically ride over seawater because of their lower density (i.e., hypopycnal plumes). Sediment settles from these plumes to the seabed because of gravity acting on particles and flocs, or because of convective instabilities (Parsons et al. 2001). Recently deposited sediment is prone to entrainment from turbulence generated at the seabed from large storm waves. Wave-generated suspensions can be highly concentrated $(>10 \mathrm{~g} /$ 1) near the seabed $(<1 \mathrm{~m})$ and result in a non-negligible gravitational component of flow on many continental shelves, despite their low slope (e.g., the Amazon, Trowbridge and Kineke 1994; northern California, Traykovski et al. 2000; southern California, Warrick and Milliman 2003; Ogston and Sternberg 1999; northern Papua New Guinea, Kineke et al. 2000). These suspensions are able to maintain themselves on the relatively flat continental shelf because, unlike turbidity currents, turbulence is 


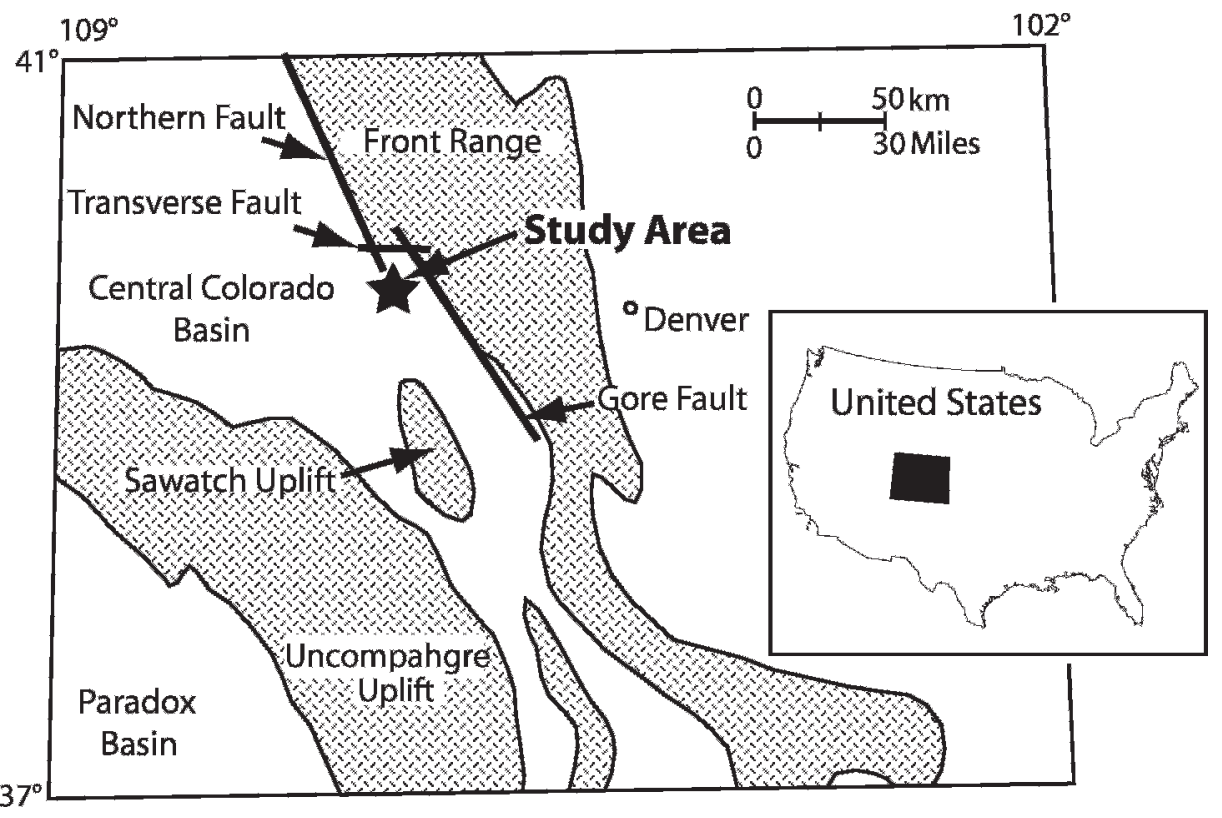

FIG. 1.-Pennsylvanian paleogeographic map of Colorado, showing uplifted areas and sedimentary basins. The location of the study area and the offset of the en echelon bounding faults on the eastern margin of the Central Colorado Basin are also shown. After Mallory (1972), DeVoto (1980), and Houck (1993). The inset map shows the location of Colorado within the United States. generated from the wave boundary layer rather than from shear produced from gravity-driven flow (Wright et al. 2001; Lamb et al. 2004a).

Rarer is the possibility that river discharge is denser than seawater. Fresh-water rivers would need to have greater than $\sim 40 \mathrm{~g} / \mathrm{l}$ of suspended sediment in order to plunge through seawater (using typical modern values of temperature and salinity). In such a case, a hyperpycnal flow develops, plunging at the river mouth to form a turbidity current (Mulder and Syvitski 1995; Mulder et al. 2003). Due to mixing of saline water into the plunging flow (Akiyama and Stefan 1984; Kassem and Imran 2001; Parsons et al. 2001), hyperpycnal flows might be possible at sediment concentrations that are lower by several orders of magnitude (Felix et al. 2006). Rivers that drain small steep catchments are most likely to produce hyperpycnal flows (e.g., Mulder and Syvitski 1995; Johnson et al. 2001; Hicks et al. 2004; Mulder et al. 2003; Warrick and Milliman 2003), although the muddy Huanghe is an important exception (Wright et al. 1986).

Myrow et al. (2002) and others (e.g., Higgs 1991; Myrow and Southard 1996) have suggested that these newly appreciated gravity-driven processes might be responsible for many marine event beds in the rock record. They coined the term "wave-modified turbidity currents" to describe hyperpycnal flows that interact with storm-generated waves in relatively shallow water. Other studies have attempted to link ancient event beds to hyperpycnal flows on the basis of a variety of evidence that is argued to be more consistent with sustained, river-derived flows than surge-type flows generated from slope failures (Plink-Björklund and Steel 2004; Pattison 2005). Such evidence includes the abundance of thick sandy turbidites, the sand-prone nature of an ancient turbidite system, a stratigraphic connection between fluvial and turbidite channels at a shelf edge, and the abundance of plant debris in turbidites (Plink-Björklund and Steel 2004). Perhaps most significant is reverse-to-normal grading within an event bed, which indicates a temporally accelerating then decelerating flow (i.e., waxing and waning sensu Kneller and Branney 1995 and Kneller 1995). Slump-driven turbidity currents are thought to be strongly waning and therefore deposit sediment sizes and structures indicative of decelerating flow (i.e., Bouma sequences). In contrast, hyperpycnal flows are expected to deposit wax-wane beds if they are directly tied to the rising and falling discharge of a flooding river (Mulder et al. 2003). Despite these recent advances, much remains unknown about cross-shelf sediment transport and the origin of sandy-event beds in the sedimentary record. What are the relative roles of failure-induced turbidity currents, hyperpycnal plumes, and wave-generated suspensions in cross-shelf sediment transport?

In this paper, we present a sedimentological analysis of event beds from a unit of prodelta deposits in the Minturn Formation of central Colorado, U.S.A. (Fig. 1). These beds were originally interpreted as turbidites deposited at water depths below storm wave base (Lindsey et al. 1986; Hoy and Ridgway 2002, 2003). Recently, however, Myrow et al. (2008) discovered that many event beds were deposited in relatively shallow water under the influence of both turbidity currents and stormgenerated waves, owing in part to the presence of large-scale asymmetric hummocky cross-stratification (HCS). In this paper, we analyze individual event beds in detail to determine the origin of the turbidity currents and their interactions with wave-generated oscillatory flow. We specifically show evidence for oscillation-dominated combined flows in proximal sections, and temporally accelerating and decelerating (i.e., waxing and waning) turbidity-current flows in distal sections. Next, we interpret the wax-wane sequences to be the deposits of hyperpycnal flows that were dynamically linked to the rise and fall of flood discharge of adjacent rivers. Finally, vertical stratification sequences and proximality trends are used to develop a conceptual model for the interaction of nearshore-generated turbidity currents with storm waves.

\section{GEOLOGIC SETTING}

The Pennsylvanian Minturn Formation was deposited along the eastern margin of the Central Colorado Basin (CCB), a feature of the Ancestral Rockies that was flanked by the Ancestral Front Range to the northeast and the Uncompahgre Uplift to the southwest (Tweto 1949) (Fig. 1). Fusulinid biostratigraphic data indicate that the event beds described herein were deposited during a relative sea-level rise in the early Desmoinesian (Stevens 1958; Tweto and Lovering 1977), interpreted to be the Inola transgression (Houck 1993, 1997), a prominent Pennsylvanian sea-level rise noted by Ross and Ross (1987). The resulting prodeltaic unit interrupts a thick succession of alluvial, fluvial, and shallow-marine deltaic lithofacies. Lithofacies patterns and stratigraphic architecture was controlled in large part by glacio-eustasy driven by glaciation within Gondwanaland (Crowell 1978; Houck 1993, 1997).

Paleogeographic and paleoenvironmental reconstructions of the formation indicate sediment transport from highlands in the north, as 
recorded in a variety of fluvial and deltaic lithofacies (Houck 1993, 1997). The prodelta unit described herein is underlain by an unconformity that spans the Atokan-Desmoinesian boundary (Houck 1993). Houck (1993) interpreted relief along this unconformity in the vicinity of Bond and McCoy, Colorado, to indicate deposition within two incised valleys. Myrow et al. (2008) conclude that both the incised valleys and interfluves were flooded during deposition of the prodelta unit owing to the scale of the HCS, which requires long-period wind-generated waves.

\section{PRODELTA UNIT}

Detailed centimeter-scale stratigraphic sections of the prodelta unit described in this paper were measured at closely spaced and timeequivalent proximal, intermediate and distal localities (localities 87-13 and $84-33$; 86-1; and 84-26, 04-1, and 85-4, respectively; Fig. 2) approximately $3 \mathrm{~km}$ along the inferred dispersal path. Distal Sections 04-1 and 85-4 are similar to 84-26 but more poorly exposed, and are not presented here (see Myrow et al. 2008). The unit ranges from 18.9 to $35.3 \mathrm{~m}$ thick and consists of approximately $30 \%$ sandstone and $70 \%$ shale on average (Table 1). The prodelta unit interrupts a thick succession of red-bed deposits that range from siltstone to coarse red-bed sandstone and conglomerate, and represents a wide variety of fan-delta lithofacies. The sandstone beds in the prodelta unit range from $<2 \mathrm{~cm}$ to over a meter thick, although most are a few centimeters to tens of centimeters thick (Fig. 3A). The beds are mainly very fine to fine sandstone, but some, particularly in more proximal localities, range up to medium to coarse sandstone. The beds are light tan-gray in color, although the coarsest beds are micaceous and darker gray to brown. Plant fossils are found in all localities and are mostly gymnosperms, including Walchia (conifer) (Fig. 3C), Samaropsis (gymnosperm seed), Cardiocarpus (gymnosperm seed), Callipteris (seed fern), and Odontopteris (seed fern; Arnold 1941; Donner 1949).

The thickness, internal sedimentary structures, vertical stratification sequences, and grain size trends of every bed greater than $3 \mathrm{~cm}$ thick were catalogued and analyzed for four sections (84-26, 86-1, 84-33, 87-13). These data are summarized in Table 1, which lists the outcrops in order

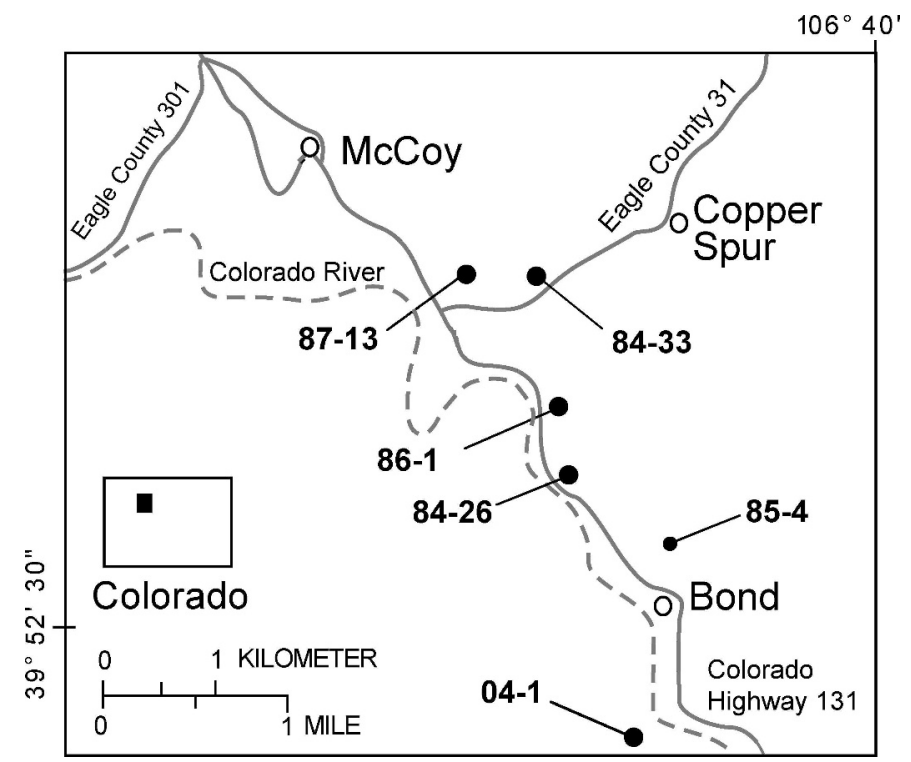

FIG. 2.- Locality map of study area. Outcrop locality numbers used in this study are from Houck (1993).

from distal to proximal. Covered intervals in the upper parts of Sections 86-1 and 84-33 skew some of the data because they preferentially occur in shale-rich, thin-bedded zones. Despite this, it is evident that thicker event beds are more abundant in the proximal sections. The spatial distribution of thick sandstone beds $(>15 \mathrm{~cm})$ suggests that individual beds likely decrease in thickness distally within this prodeltaic unit (Table 1). In proximal localities, sandstone beds contain fewer prominent vertical changes in grain size and sequences of sedimentary structures (Table 1). Rather, these localities contain individual massive, planar- and quasiplanar-laminated, and HCS beds, indicating deposition under combined oscillatory and unidirectional flow. In contrast, at distal localities beds

TABLE 1.-Characteristics of event beds, percentages of beds with a particular vertical sequence of sedimentary structures, and percentages of beds with a particular type of grading. All event beds greater than $3 \mathrm{~cm}$ thick were documented. Two or more sedimentary structures are required to form a sequence. Event beds that only had one structure are listed under "No sequence." These beds typically contain planar lamination or massive bedding. Beds with sequences are grouped by the flow conditions in which they were deposited. For example, a partial or full Bouma sequence is designated a "waning" bed sequence. All beds that show significant wave influence because of hummocky-cross stratification (HCS) or quasi-parallel lamination (QP) are grouped together. The bed sequences grouped as "other intermediate" have wane-wax sequences or multiple stacked sequences (e.g., wane-wax-wane). The bed sequences grouped as "other" are normal-to-reverse grading or multiple grading divisions that indicate pulsing within the flow.

\begin{tabular}{|c|c|c|c|c|c|}
\hline Localities & & \multicolumn{2}{|c|}{ Proximal } & $\begin{array}{c}\text { Intermediate } \\
86-1\end{array}$ & $\begin{array}{r}\text { Distal } \\
84-26 \\
\end{array}$ \\
\hline & Section thickness (m) & 12.4 & 35.3 & 19.8 & 18.8 \\
\hline & Number of event beds & 24 & 81 & 38 & 60 \\
\hline & Beds $>15 \mathrm{~cm}$ thick $(\%)$ & 39 & 35 & 16 & 19 \\
\hline \multirow[t]{4}{*}{ Structure sequence } & Waning sequences (\%) & 4 & 10 & 26 & 38 \\
\hline & Waxing sequences $(\%)$ & 4 & 2 & 3 & 10 \\
\hline & No sequence (\%) & 71 & 54 & 29 & 25 \\
\hline & Other $(\%)$ & 0 & 1 & 5 & 8 \\
\hline \multirow[t]{4}{*}{ Grading } & Normal (\%) & 4 & 4 & 21 & 25 \\
\hline & Reverse (\%) & 8 & 4 & 5 & 5 \\
\hline & Reverse-normal (\%) & 0 & 0 & 3 & 35 \\
\hline & No grading (\%) & 88 & 90 & 71 & 30 \\
\hline
\end{tabular}

\footnotetext{
* Only lower portion of section was measured.
} 

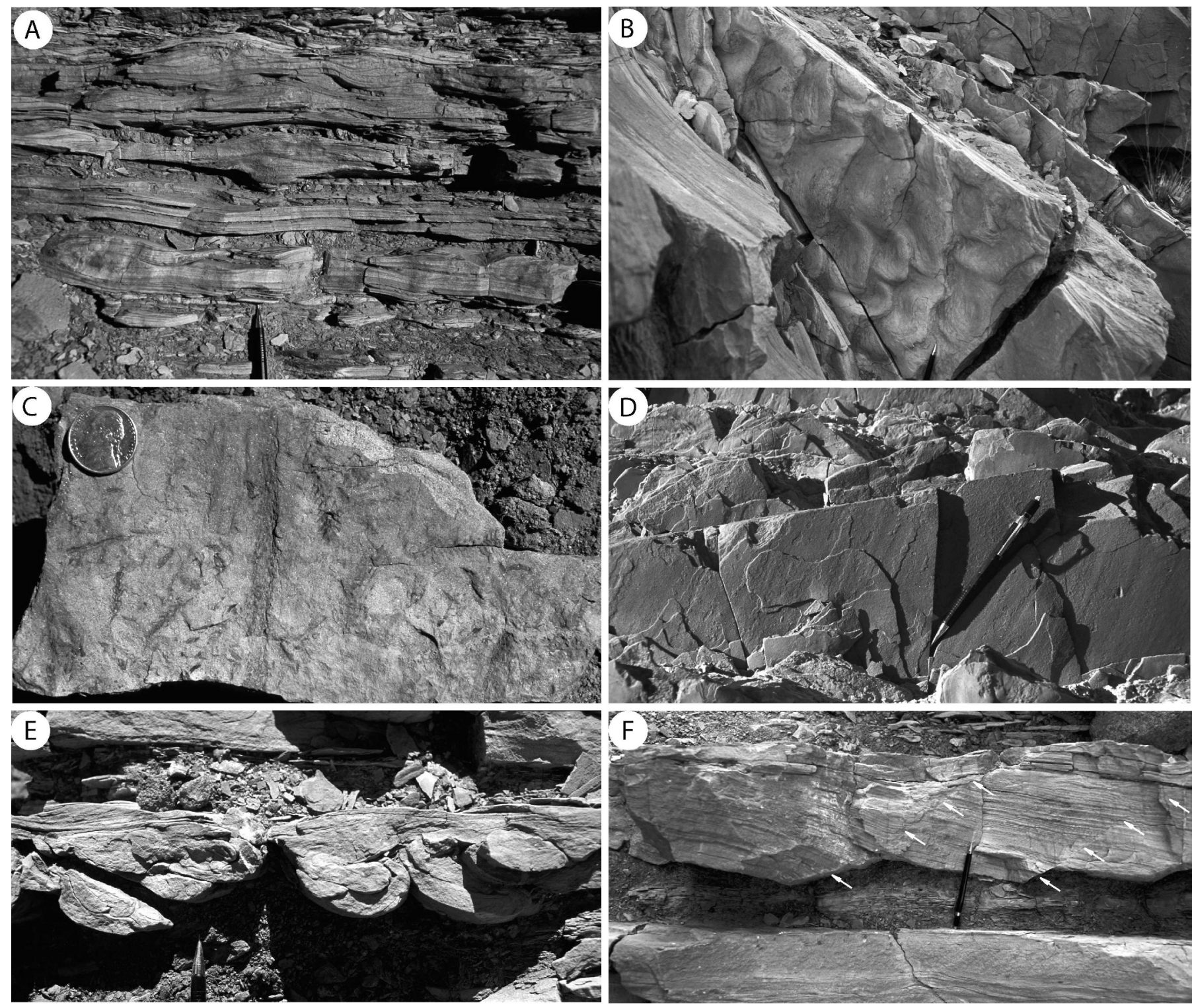

FIG. 3.-Sedimentary features (pencil for scale is $14 \mathrm{~cm}$ long and tip is $2 \mathrm{~cm}$ long). A) General character of sandstone and shale beds in the turbidite unit. Note ripple cross-stratified and parallel-laminated beds, and irregular upper and lower surfaces of beds. B) Ripples on bedding plane at 17.57 m of section 84-26. C) Walchia fossils in float from section 84-33. Nickel for scale is $2 \mathrm{~cm}$ in diameter. D) Parting lineation in parallel-laminated bed at $1.93 \mathrm{~m}$ of section 84-26. E) Asymmetrical ball-and-pillow structures at $17.25 \mathrm{~m}$ of section 84-26. F) Sandstone bed with synsedimentary faults at $17.35 \mathrm{~m}$ in section $84-26$. Note offset of the base of the bed along the faults (arrowed).

are commonly graded and contain sequences of sedimentary structures that indicate deposition primarily under strong unidirectional flow (Table 1). The characteristics of proximal and distal deposits are described separately below.

\section{PROXIMAL AND INTERMEDIATE DEPOSITS}

The two most proximal outcrops, 84-33 and 87-13 (Fig. 2), contain similar sandstone event beds (Table 1). For brevity only the stratigraphic section for location 84-33 is presented (Fig. 4). The proximal event beds tend to be thicker than in more distal settings (Table 1), in some cases up to $94 \mathrm{~cm}$ thick. These event beds are also coarser-grained and range from coarse- to medium-grained sandstone, whereas siltstone to fine sandstone dominates the more distal sections. The coarser-grained beds are commonly structureless, and most show no grading (Table 1). Finer- grained beds display small- and large-scale hummocky cross-stratification (HCS), parallel lamination, quasi-planar lamination (Arnott 1993), and combined-flow-ripple cross-stratification (i.e., rounded crests and convexup or sigmoidal foresets) (Fig. 5). The HCS beds range up to $50 \mathrm{~cm}$ thick and contain well-preserved hummocks, which are generally asymmetric with steeper ends to the south, which was seaward at the time (Houck 1993, 1997). The apparent spacing of hummocks on vertical outcrop faces range from a few decimeters to $1 \mathrm{~m}$ or more (locally up to 2-3 m), and heights are in many cases up to a few tens of centimeters. Many of these beds show evidence of decelerating flow, including capping divisions of lamination produced by climbing combined-flow ripples.

The prodelta unit at intermediate locality 86-1 (Fig. 6) has characteristics that are intermediate between the proximal and distal localities. The sandstone beds show examples of small-scale HCS, quasi-planar lamination, and combined-flow ripples like those of the proximal 

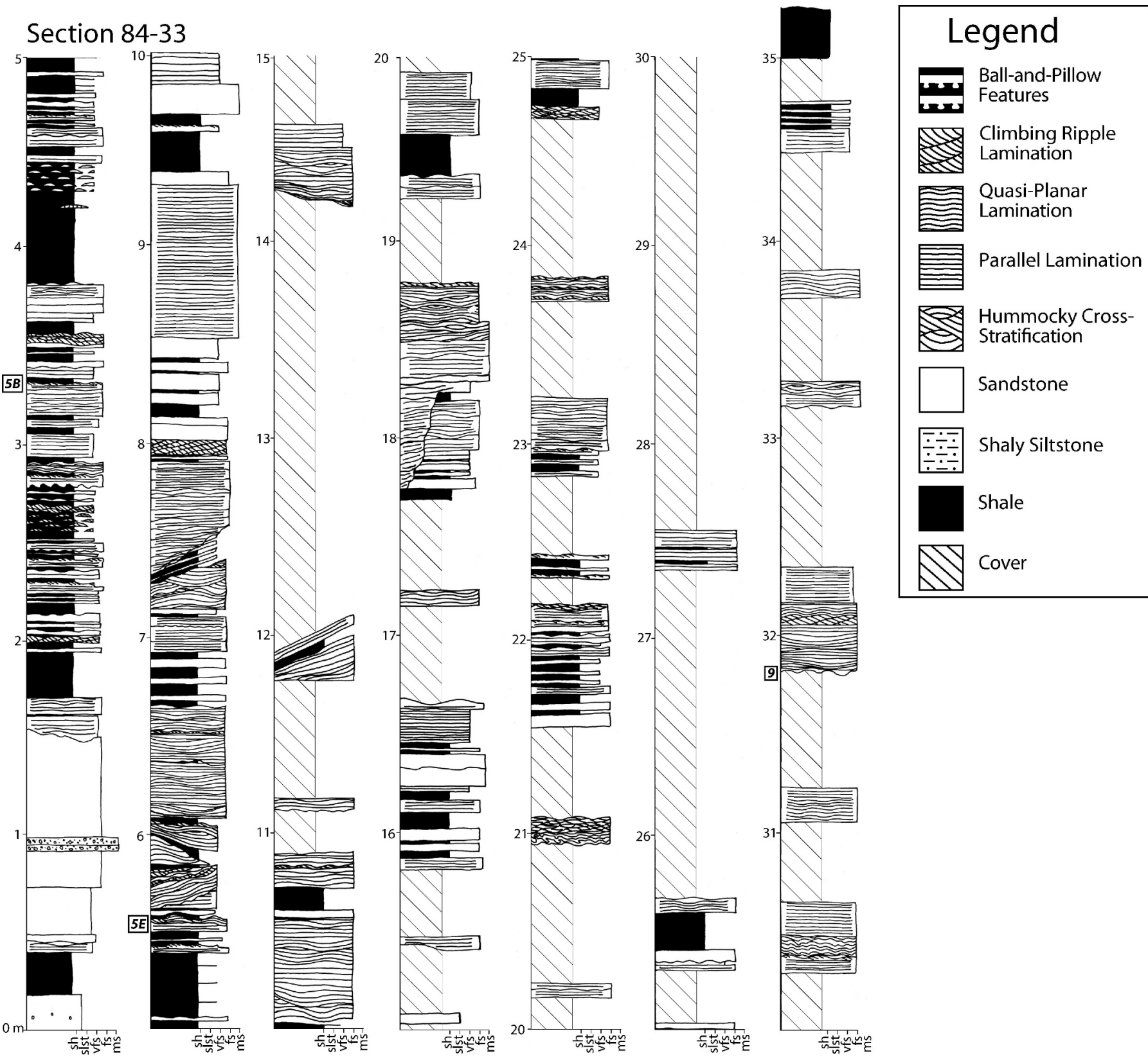

FIG. 4.- Stratigraphic section for location 84-33 (see Fig. 2 for location). The vertical scale is in meters and the horizontal scale denotes grain-size categories: shale (sh), shaly siltstone (slst), very fine sand (vfs), fine sand (fs), and medium sand (ms). The labels within the small squares to the left of some beds correlate with the figure numbers for corresponding photographs. The labels $R N G$ or $W W$ marked to the right of some beds indicate that they contain reverse-to-normal grading (RNG) or sedimentary structures that indicate waxing-to-waning flow (WW). See legend for sedimentary structures and textures.

sections. However, the beds are generally thinner and also show normal grading, partial and complete Bouma sequences, and well-developed sole markings. A particularly interesting bed, exposed at $11.62 \mathrm{~m}$ at Section 86-1, contains large-scale HCS at its base and combined-flow-ripple lamination on top (Figs. 7, 8). The geometry of the HCS indicates a relatively symmetrical to slightly asymmetrical bedform with spacing on the order of several meters. The ripple cross-stratification in this bed is developed over a large-scale hummocky bedform surface, and the ripple paleocurrents are oriented southward. On the southern (downstream) end of the HCS bedform a thick (up to $15 \mathrm{~cm}$ ) succession of combined-flowripple cross-stratification is preserved. However, time-equivalent stratifi- cation on the northern (upstream) end of the bedform show only a few poorly developed ripples preserved within parallel lamination.

A variety of sole marks are preserved on these events beds, although there are fewer exposures of bedding soles than the distal sections. Groove, drag, chevron, and prod marks are common, and flute marks, although less common, also exist, particularly in thicker beds with parallel lamination and HCS. Near the top of Section 84-33, at $31.8 \mathrm{~m}$, is a prominent $38-\mathrm{cm}$-thick sandstone bed with spectacular large-scale sole marks (Fig. 9) that include deep and wide groove marks, flute marks, and gutter casts. Small grooves and prod marks cover much of the surface, including the surfaces of the gutter cast and larger grooves. The grooves 

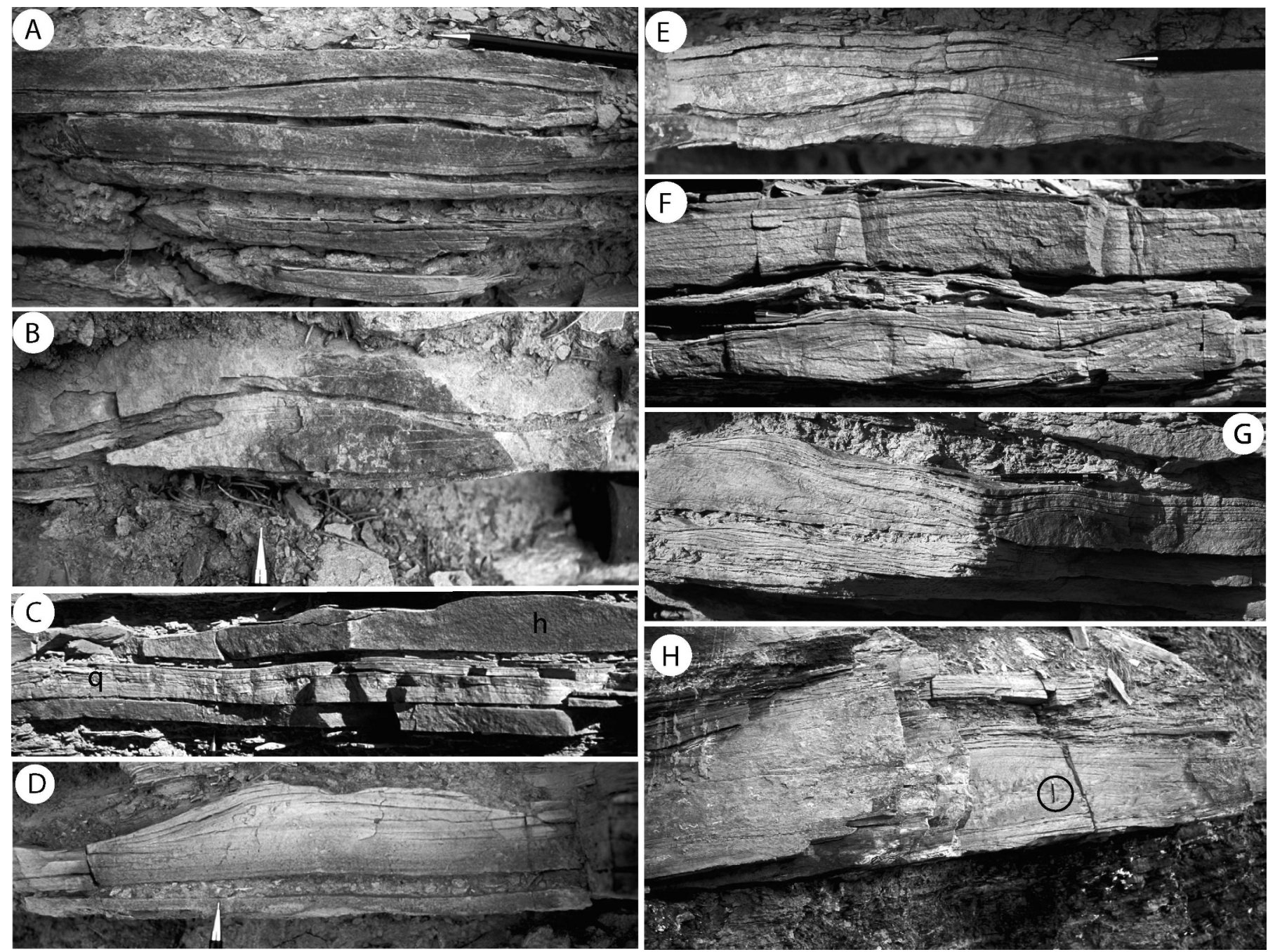

\%

FIG. 5.-A) Small-scale HCS from 6.3 to $6.8 \mathrm{~m}$ in Section 86-1. B) Combined-flow-ripple lamination from $3.29 \mathrm{~m}$ of section 84-33. Note nearly symmetrical cross section, rounded crest, and convex-up foresets. C) Quasi-planar laminated (q) and HCS (h) beds from $3.1 \mathrm{~m}$ of section 84-26. D) Parallel lamination and well-preserved hummocky bedform from Section 84-33. E) Combined-flow-ripple lamination from $5.61 \mathrm{~m}$ of section 84-33. F) Lower bed with combined-flow-ripple lamination and draping lamination and upper bed with parallel lamination from $14.85 \mathrm{~m}$ of Section 84-26. G) Three-dimensional view of small asymmetric hummocky bedform from $2.01 \mathrm{~m}$ at Section 87-13. Ripple-scale bedform at top of hummock in upper left shows migration to south, reflecting migration under combined flow. $\mathbf{H})$ Thick, large-scale HCS bed from an unmapped outcropping $3.5 \mathrm{~km}$ east of McCoy, CO. Pencil for scale is circled. Pencil in photos is $14 \mathrm{~cm}$ long and tip is $2 \mathrm{~m}$ long.

are up to $50 \mathrm{~cm}$ long and $4 \mathrm{~cm}$ wide, and the flute marks are up to $3 \mathrm{~cm}$ across and $1 \mathrm{~cm}$ deep. The gutter cast is $9 \mathrm{~cm}$ across and $2 \mathrm{~cm}$ deep. The lower division of the overlying bed consists of $10-15 \mathrm{~cm}$ of massive medium sandstone. The rest of the bed is parallel laminated with minor HCS and combined-flow ripples. Tool marks display very strong orientations towards the southwest at localities 87-13 and 84-33, and are oriented generally SSE at locality 86-1 (Fig. 10).

\section{DISTAL DEPOSITS}

At distal Section 84-26 the turbidite unit is 18.9 m thick (Fig. 11). The strata at this locality are conspicuously different from the more proximal outcrops described above in that the beds are generally thinner, contain very little medium-grained or coarser sandstone, and lack sedimentary structures commonly attributed to complex oscillatory and combined flows, such as quasi-planar lamination (Arnott 1993) and hummocky cross-stratification (Table 1). Instead, their general character shows deposition under unidirectional-current-dominated flows. These event beds show prominent normal and reverse-to-normal grading $(60 \%$ of beds; Table 1). Internal sedimentary structures are diverse and include features common to turbidites, such as normally graded divisions, massive bedding, parallel lamination, and ripple cross-stratification (Fig. 12). Figure 13 offers a graphical representation of the most common vertical successions of structures within the beds at the distal localities. In many instances, these are arranged in partial (Figs. 12E, 13A, B) or complete Bouma sequences (Figs. 12D, 13C).

Twenty percent of the event beds at distal locality 84-26 contain sedimentary structures indicative of waxing flow, and half of these record waxing to waning flow during a single flow event (Table 1). Waxing and waning flow is also recorded in vertical changes in grain size. For instance, $35 \%$ of the event beds at Section $84-26$ have reverse-to-normally graded beds (Table 1). Stratification sequences in these wax-wane beds typically begin with ripple cross-stratification, followed by planar lamination or massive sandstone, and capped with another division of ripple cross-stratification at the top of the bed (Figs. 12A, F, 13I). Other, less common vertical stratification sequences also record waxing to 

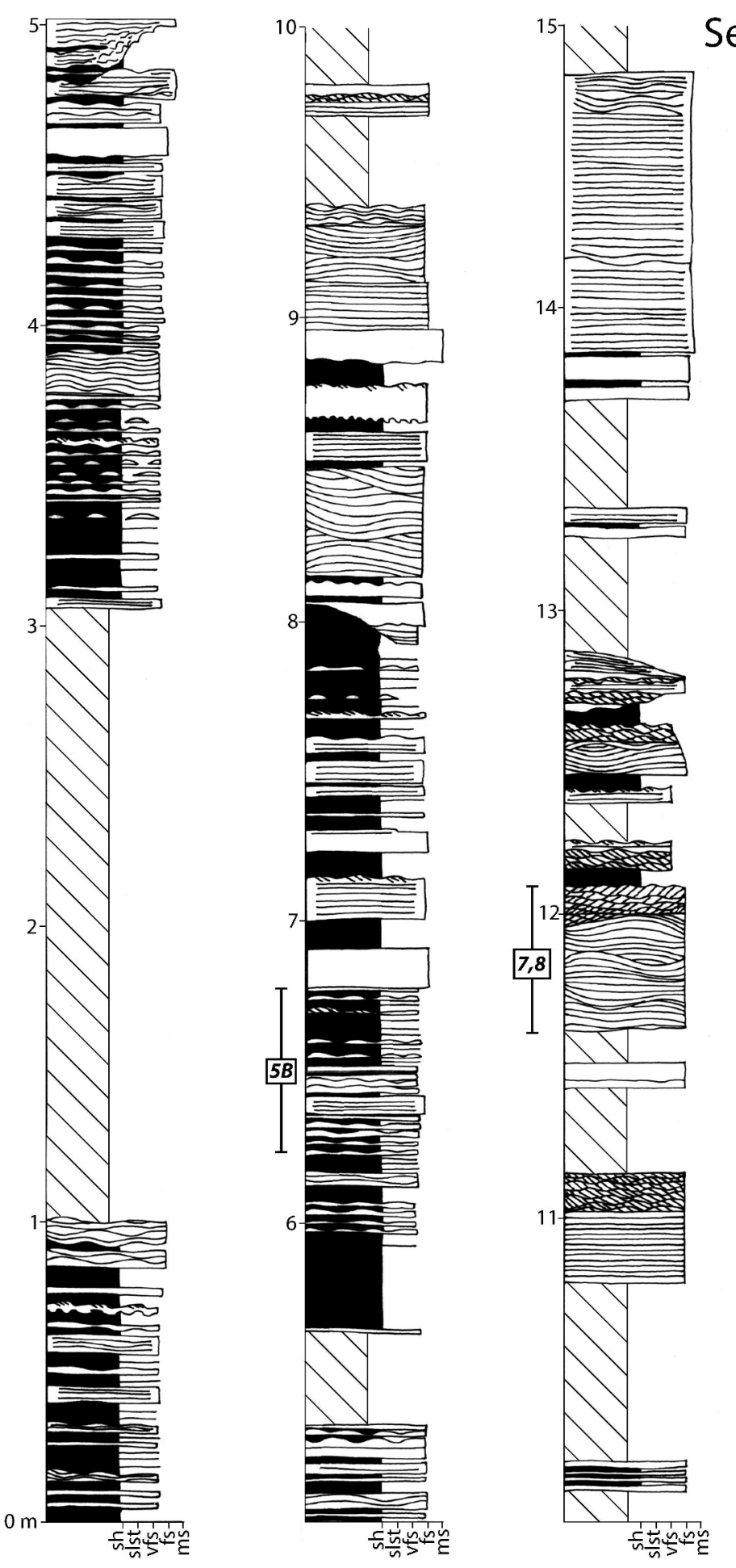

Section 86-1

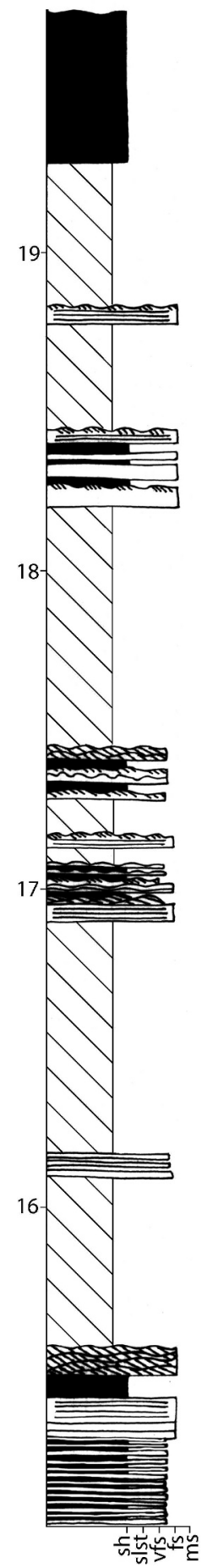

FIG. 6.-Stratigraphic section for location 861. See caption to Figure 4 for legend and symbols. waning flow (Fig. 13H, J). In many cases the reverse-to-normal grading takes place over a large proportion of the bed thickness (Fig. 12A, C, F, G), although some beds show the reverse grading solely within the lowermost division (Fig. 13L, N). A few beds show abrupt changes in grain size (e.g., fine to coarse sandstone; Fig. 13J), although for most beds the grading is gradual with no indication of bypass surfaces.

Whereas the ripple cross-stratification in more proximal localities contains prominent features typical of deposition under combined flows (i.e., rounded crests and convex-up or sigmoidal foresets), in distal localities the stratification is more typical of ripples developed under unidirectional flow. Ripple migration directions at this locality are oriented SSW (Fig. 10). Sole marks are very abundant, particularly in float, and these include grooves, prods, flutes, and chevron structures at various scales (Fig. 14). Paleocurrent orientations of these sole marks are scattered across the southwest quadrant (Fig. 10). These orientations are consistent with a generally southward, downslope direction as inferred from a number of secondary sedimentary features related to gravitational instability (discussed below). 
Changes in grain size are generally closely associated with changes in sedimentary structures, and particular grain sizes are usually associated with specific sedimentary structures. Coarse and medium sandstone is commonly massive or planar laminated; very fine to fine sandstone is commonly planar laminated; and siltstone to very fine sandstone is commonly associated with combined-flow-ripple lamination (Figs. 12, 13).

\section{Paleoslope Orientations from Synsedimentary Deformation Structures}

Ball-and-pillow structures occur in most sections and are generally small in scale $(<10 \mathrm{~cm})$, although they occur in sandstone beds up to $30 \mathrm{~cm}$ thick. Some of the ball-and-pillow structures are notably asymmetric (Fig. 3E). By assuming downslope deformation due to gravity in the direction parallel to the asymmetry and perpendicular to the long axes of the structures, an inferred paleoslope direction can be measured (Myrow et al. 2002). The data are meager $(n=5)$, but all measurements range from SE to WSW (an additional reading on symmetric ball-and-pillows indicate an elongation direction of $268^{\circ}$, consistent with the other readings) (Fig. 10). A bed at $17.35 \mathrm{~m}$ at Section 84-26 shows evidence for failure contemporaneous with deposition. Planar to slightly concave-up synsedimentary normal faults in this bed (Fig. 3F) show hanging-wall displacement towards the south (direction of extension), once the data were subjected to stereonet rotation to account for the strike and dip of bedding.

\section{PROCESS INTERPRETATIONS}

\section{Proximal to Intermediate Deposits}

The Minturn event beds described herein contain a wide variety of sedimentary structures, paleocurrent data, and facies characteristics that allow the interpretation of depositional processes. Our observations from proximal and intermediate sections of wave-generated stratification such as HCS, quasi-planar lamination, and combined-flow ripples indicate that many beds were deposited in relatively shallow water under the influence of combined flows with current and wave components. The nature of the ripple stratification and preserved ripple foresets are characteristic of deposition under relatively weak oscillation-dominated combined flows (Arnott and Southard 1990; Myrow and Southard 1991; Yokokawa 1995; Yokokawa et al. 1995; Myrow et al. 2002; Dumas et al. 2005). The sigmoidal form of combined-flow ripples indicates that foresets were not formed by simple avalanching of sand grains, but in association with vortices formed in the troughs of the ripples (Yokokawa 1995; Yokokawa et al. 1995).

Higher-energy oscillatory flow is recorded by the presence of small- to large-scale HCS and quasi-planar lamination. HCS is well documented in both experimental and field studies to result from long-period complex oscillatory flow or wave-dominated combined flow (Harms et al. 1975; Duke 1990; Duke et al. 1991; Southard et al. 1990; Arnott and Southard 1990; Dumas et al. 2005). Quasi-planar lamination is the product of deposition near the stability-field boundary between hummocky bedforms and upper plane bed, presumably under combined-flow conditions (Arnott 1993). The sedimentary structures in the HCS bed at $11.62 \mathrm{~m}$ at Section 86-1 (Figs. 7, 8), and their distribution, are an extraordinary example of the combined-flow origin of some HCS. This bed shows a clear response to deposition under waning combined flow, as recorded by the upward transition from HCS to combined-flow-ripple lamination (Arnott and Southard 1990; Southard 1991; Dumas et al. 2005). We interpret the prevalence of parallel lamination on the upstream end of the HCS bedform to reflect downstream flow acceleration caused by the positive relief of the hummock. In the lee of the hummock, flow expansion led to a reduction in velocity and the production of ripples. The asymmetric distribution of these structures could only have resulted from unidirectional flow in the presence of waves, with the southern, lee side of the hummock in the downstream position relative to the unidirectional component of the combined flow.

The asymmetric geometry of much of the HCS in this study, with steeper sides to the south (distal), preferential inferred migration of hummocks to the south, and the presence of intimately associated combined-flow-ripple cross-stratification with migration directions exclusively to the southern quadrants, all indicate that many of the beds were deposited under combined flows. Interestingly, unidirectional sole marks have been preserved at the base of some HCS beds indicating strong unidirectional flow or unidirectional-current-dominated combined flow (Myrow and Southard 1996) during the pre-depositional phase of the bed. Myrow and Southard (1996) argued that flutes with classic V-shaped geometries and steep upstream snouts (Fig. 14C, D) are not formed in oscillatory flows and are not likely to be formed in combined flows when the oscillatory flow component exceeds the unidirectional flow component (i.e., in combined flows that have a reversing flow direction).

One of the intriguing aspects of these beds is that despite the abundance of features formed by combined flows, there is almost no evidence for deposition under simple oscillatory flow, e.g., classic (2D) wave ripples with sharp, symmetric, and linear crests. This likely indicates that deposition occurred under combined-flow conditions during storms, and that postdepositional reworking by waves in the prodelta did not take place. Thus, the temporal effects of waves waned before the associated unidirectional component of combined flow, and prior to final deposition during the event.

\section{Distal Deposits}

In contrast to the strong oscillation-dominated combined flows in proximal locations, the beds at more distal outcrops show evidence for powerful unidirectional currents, particularly during the early erosive stages of flow, as indicated by grooves, prods, gutter casts, and flutes with distinct south and west flow orientations (Figs. 10, 14; Houck 1993, 1997). Both direct and indirect evidence suggest that the unidirectional component of flow in these strata was in the downslope direction driven by negative buoyancy supplied by suspended sediment (i.e., a turbidity current). First, paleocurrent indicators (ripple stratification and sole marks) indicate net southward flow, which is the downslope direction as shown by regional paleogeographic and paleoenvironmental reconstructions (Houck 1993, 1997) and the ball-and-pillow structures and synsedimentary normal faults (Fig. 10). Second, the sandstone beds contain classic features of turbidites, namely abundant sole markings, graded bedding, and Bouma sequences. As mentioned earlier, these features led numerous previous authors to interpret this unit, and broadly time-equivalent deposits, as turbidites (Lindsey et al. 1986; Schenk 1986; Houck 1993; Hoy and Ridgway 2002, 2003). Lastly, these distal deposits were deposited in the absence of oscillatory currents (i.e., below storm wave base) and therefore were not formed from in situ resuspension by storm waves. A number of possibilities exist for the generation of these turbidity currents, which are discussed in the next section.

\section{NATURE OF THE EVENTS}

As discussed above, there is strong evidence that the distal event beds are deposits from turbidity currents. Were these distal turbidite beds deposited from the same flows that created the more proximal event beds? Four aspects of the spatial transition between distal and proximal outcrops suggest that proximal event beds are genetically linked to the distal turbidites. First, bed-thickness patterns from proximal to distal outcrops crudely mimic standard proximality trends for event beds (Aigner 1982, 1985; Walker 1984; Brenchley 1985; Pederson 1985; Handford 1986), particularly the distal decrease in bed thickness, which indicates that the flows in question were depletive (Kneller 1995). Second, 


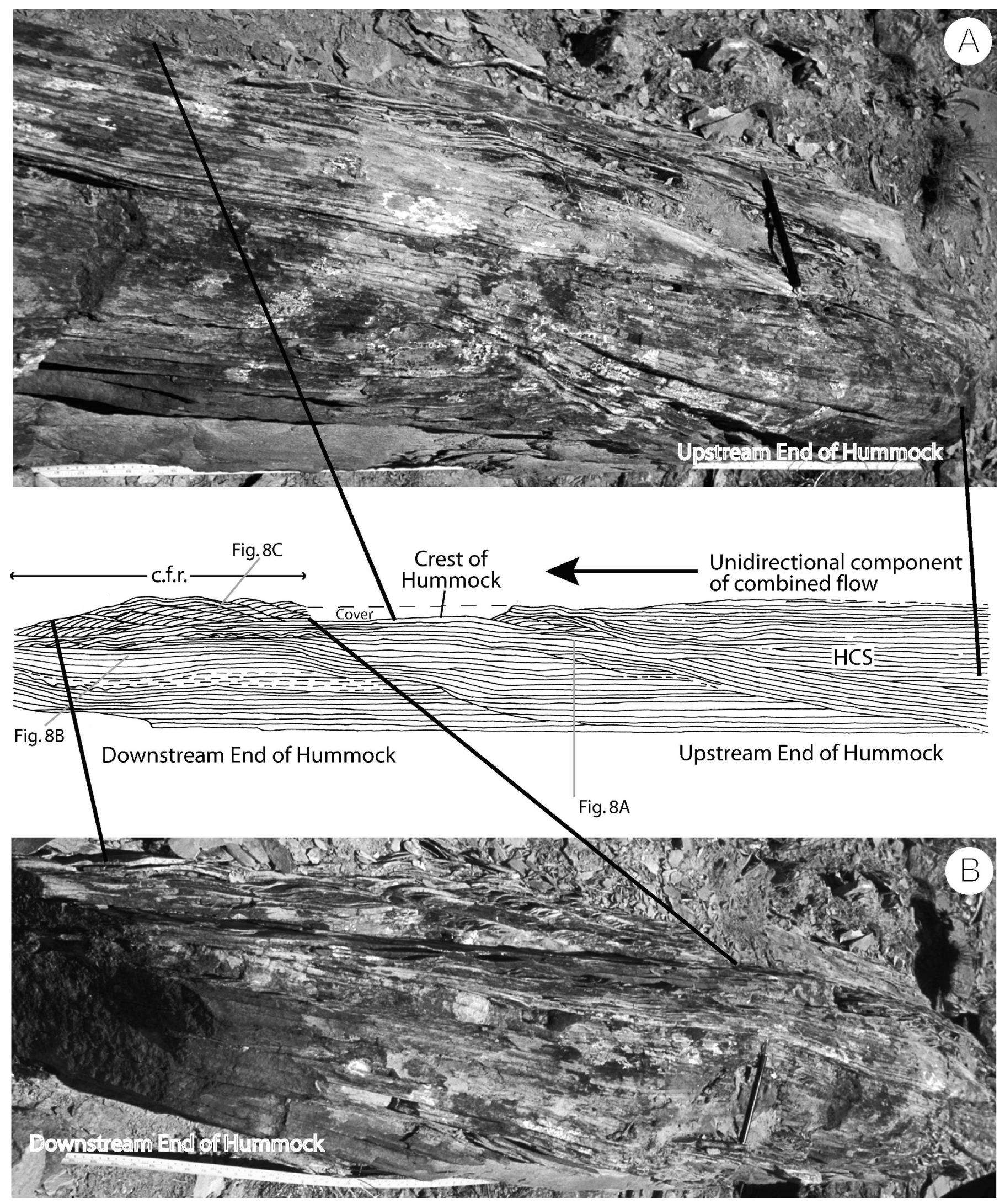

FIG. 7.-Detailed sketch of bed at $11.62 \mathrm{~m}$ at Section 86-1 showing large-scale HCS at its base and combined-flow ripples on top. Ripple stratification is up to $15 \mathrm{~cm}$ thick on the southern (downstream) end of the underlying HCS bedform. Time-equivalent stratification on the upstream end of the bedform shows only a few poorly developed ripples preserved within parallel lamination. The distribution of ripple stratification, all of which shows southward flow, reflects flow acceleration on the upstream end of the hummock and flow expansion on the downstream side. Pencil is $14 \mathrm{~cm}$ long. 

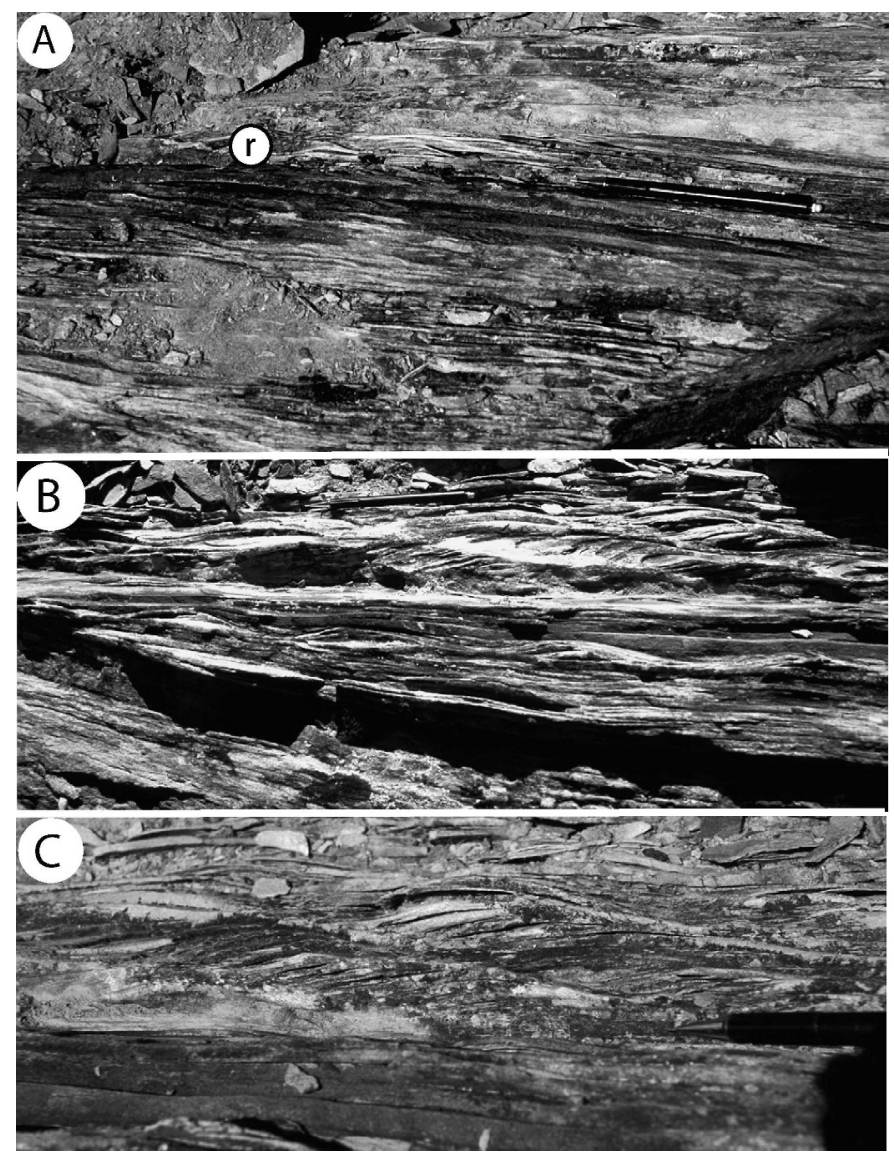

FIG. 8.- Close-up views of bed shown in Figure 7. A) Upstream end of hummock with mostly planar lamination of hummocky and minor combined-flowripple lamination $(\mathrm{r})$. B) Thick $(15 \mathrm{~cm})$ division of combined-flow lamination on upper part of downstream end of hummock. C) Close-up of Part B showing combined-flow-ripple lamination. Note well-developed convex-up foreset laminae. Pencil in photos is $14 \mathrm{~cm}$ long and tip is $2 \mathrm{~cm}$ long

although individual beds cannot be traced laterally, the unit can be walked out with only scattered cover for the short distances between outcrops (in some cases, less than $1 \mathrm{~km}$ ), and there is little change in the first-order character of these deposits (e.g., number of events, percentage of sandstone (Table 1), and particle sizes and compositions). Third, at intermediate Section 86-1 (Fig. 6), thinner event beds with turbidite features are interbedded with thicker beds with $\mathrm{HCS}$, indicating a potential transition region between these two styles of deposits. Lastly, the paleocurrent indicators in proximal deposits indicate flow in the same direction as those in distal outcrops, to the southern quadrants, which is consistent with the inferred downslope direction (discussed above). Important is the dominance of strong unidirectional (not bidirectional) sole marks at the base of the proximal deposits, indicating powerful unidirectional-current-dominated flow, at least initially during the event, which was charged with woody debris

It is unlikely that the unidirectional component of the combined flows in proximal sections arose from something other than turbidity currents. The most common response of nearshore oceanographic systems to storm-generated wind is the development of geostrophic currents, nearly shore-parallel (not downslope) flows created by a combination of coastal setup and deflection by the Coriolis force. Storm-generated currents, however, might have been directed more offshore due to the low latitudes of the Central Colorado Basin during the Pennsylvanian (Johnson et al. 1992), because the Coriolis force would have been weak. Wave-generated
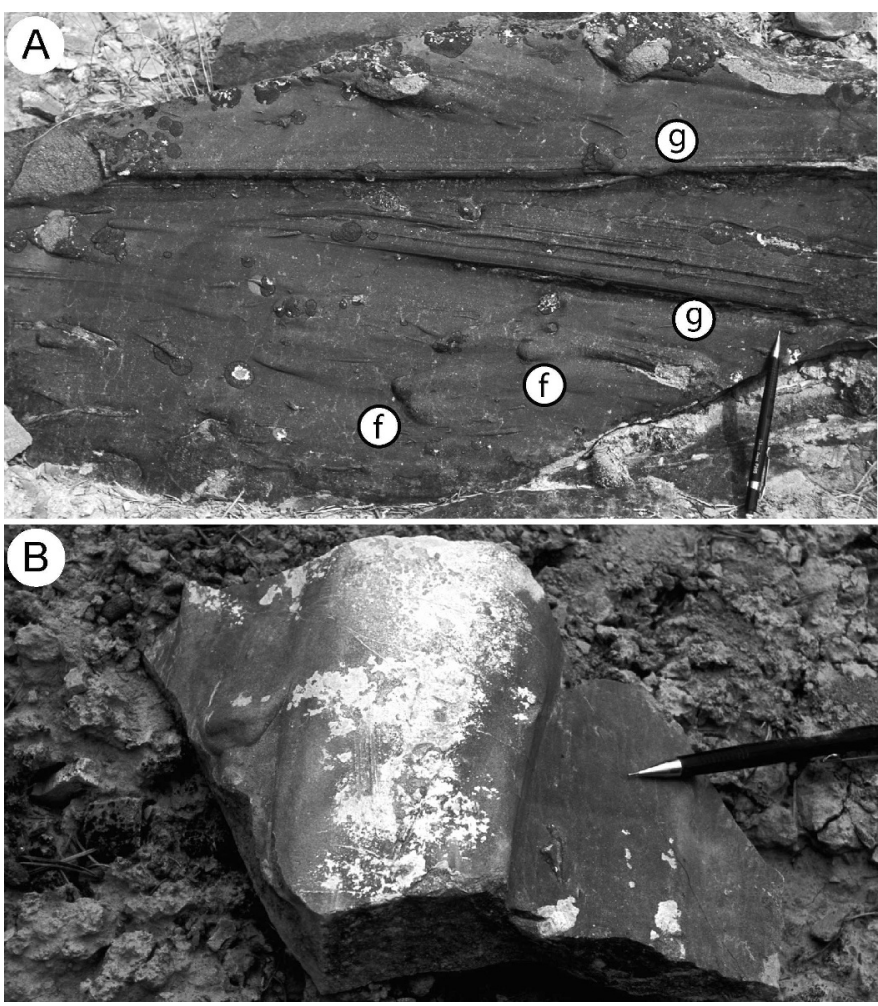

FIG. 9.-A) Large grooves (g) and flute marks (f) on base of HCS sandstone at $31.81 \mathrm{~m}$ of section $84-33$ (Fig. 4). B) Large gutter cast from base of same bed as shown in Part A. Pencil is $14 \mathrm{~cm}$ long.

suspensions that move slowly downslope under the influence of gravity (e.g., fluid mud) are unlikely to have formed the event beds because the sole marks (e.g., flutes) indicate periods of powerful unidirectionalcurrent-dominated flow, not oscillation-dominated flow (Myrow and Southard 1996). The possibility that tidal currents might represent the unidirectional component of these combined flows also seems unlikely because tidal features (e.g., herring-bone cross-bedding, tidal bundles) are not represented in any of the marine and marginal marine deposits in the Minturn Formation. In addition, the epicratonic setting with strong frictional forces within a shallow semi-restricted seaway probably would not have generated strong tides, as demonstrated for other epicratonic seas (e.g., Ericksen and Slingerland 1990).

Given the close proximity of the intermediate and proximal outcrops to the distal turbidite beds, and the consistent downslope-oriented paleocurrent indicators in both proximal and distal outcrops, it seems most plausible that the event beds in proximal settings are the result of deposition from the same turbidity currents that traversed distal sections. If so, then the seaward transition from oscillation-dominated combined flow to unidirectional flow probably resulted from a distal decrease in the magnitude of storm-generated oscillatory flow at the seabed due to increasing water depth. Evidence for this comes from intermediate Section 86-1, which has a more nearly equal percentage of beds reflecting unidirectional-current-dominated flow (partial to whole Bouma sequences) and oscillation-dominated flow (HCS), than either the distal or proximal settings (Table 1). Thus, the turbidity currents traveled through a zone of wave influence in the proximal prodelta and were less influenced by waves farther seaward.

There are only a few mechanisms by which turbidity currents could have been generated within the ancient prodeltaic setting. The fact that beds with turbidite features, including those with wave-generated 

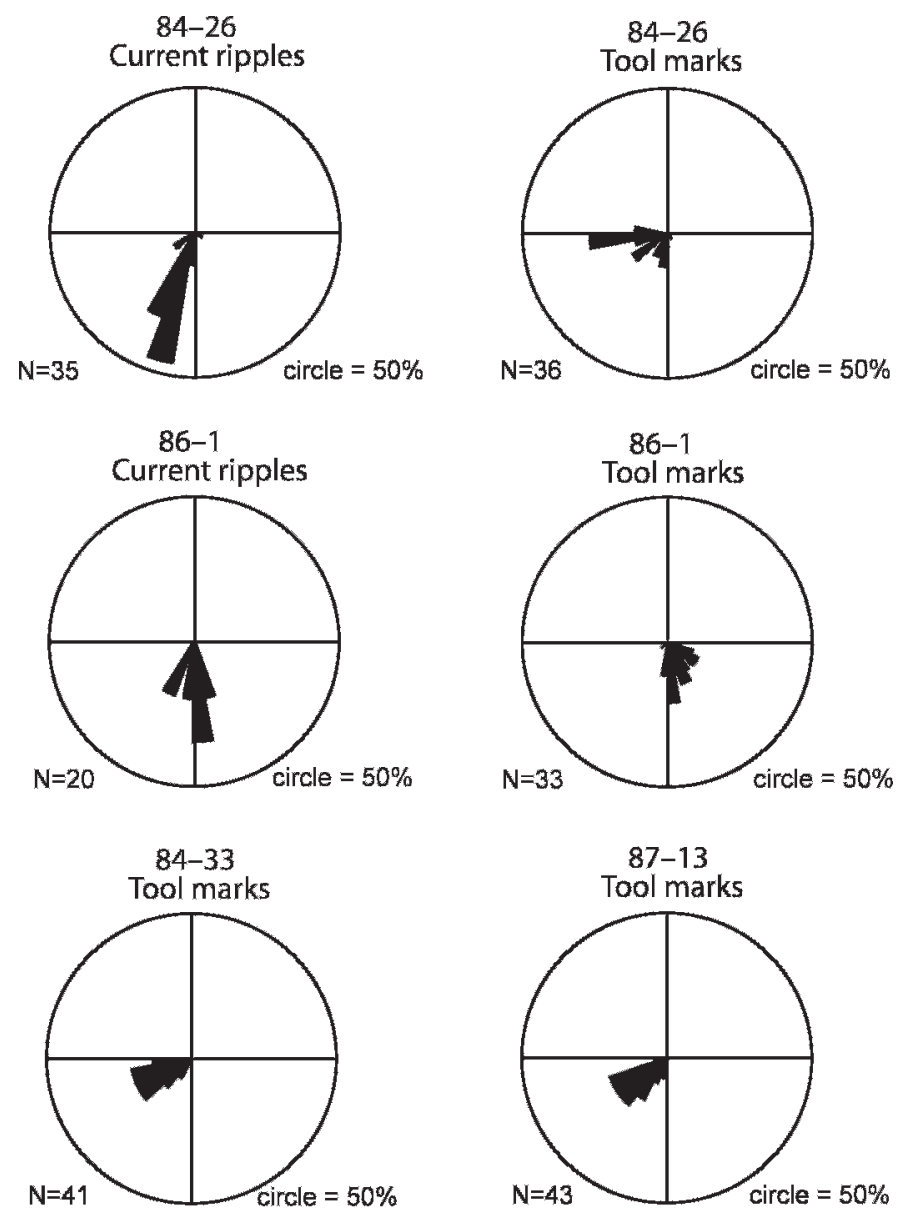

Asymmetric Ball and Pillow

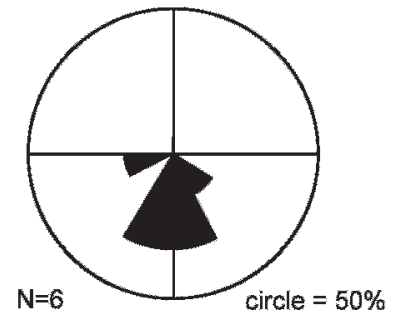

FIG. 10.- Rose diagrams for paleocurrent indicators from current ripples and tool marks from field sites shown in Figure 2 (modified from Houck 1993). The diagrams are scaled so that the circle represents $50 \%$ of the indicators, and the number of indicators is given by $N$. Also shown is a rose diagram showing inferred downslope direction for gravitationally generated asymmetric ball-and-pillow structures (c.f. Myrow et al. 2002) taken from various localities.

stratification, are present even in the proximal deposits indicates that the turbidity currents must have been generated relatively nearshore. It is possible that slumps or retrogressive failures (van den Berg et al. 2002) generated currents formed in the delta front, possibly in mouth bars, and then evolved into turbidity currents. It has been argued based on experimental observations (Mohrig and Marr 2003) and theoretical grounds (Swift 1985), however, that the conversion of a debris flow into a turbidity current is inefficient, especially on the low slopes typical of nearshore settings. One also might expect sandy slump and debris-flow deposits on the prodelta, and no such features have been noted (although muddy debris flow deposits do occur in the lower few meters of some distal sections, as discussed by Myrow et al. 2008).
A second possible mechanism for initiating turbidity currents near shore during storms is through generation of hyperpycnal river plumes. This part of the Minturn Formation was deposited in close proximity to rangebounding faults less than $20 \mathrm{~km}$ to the east and north (Fig. 1), and these would have generated small steep catchments and possibly earthquakes, and thus high suspended-sediment concentrations and flashy discharges during runoff (e.g., Dadson et al. 2005). This geographic setting is similar to modern environments that are prone to producing hyperpycnal flows (Mulder et al. 2003). Although such features are not restricted to hyperpycnal-flow deposits, the abundance of parallel lamination and thick climbing-ripple cross-stratification is consistent with deposition from hyperpycnal flows. Both form under conditions of high fallout of suspended sediment (Arnott and Hand 1989), and both are interpreted to be common features of modern (Nakajima 2006) and ancient (Zavala et al. 2006) hyperpycnites. Also important is the abundance of the plant fossil Walchia in the turbidite beds. It is notable that this plant fossil is absent in all other marine and marginal marine facies in the Minturn Formation, which contain other plant fossils that grew in lowland settings, such as Calamites (sphenopsid) and Stigmaria (lycopsid). Pennsylvanian conifers such as Walchia were upland plants, living in environments that were water stressed for at least part of the year (G. Rothwell, personal communication). Its sole presence in the event beds is consistent with the idea that storm events catastrophically drained dry upland areas adjacent to the Minturn basin, and fed rivers highly charged with sediment and plant debris that plunged below the sea surface. The last major line of evidence in support of the hyperpycnal-flow hypothesis is the presence of both reverseto-normal grading and wax-wane vertical stratification sequences, which is discussed below in detail.

\section{Wax-Wane Beds}

Particular depositional conditions are required to preserve beds that display reverse-to-normal grading and vertical sequences of sedimentary structures that indicate waxing-to-waning flow, and these are thought to be common in hyperpycnal flows (Mulder et al. 2003). These flows can have a waxing phase lasting for as long as days, mimicking the hydrograph of a flooding river (Mulder and Syvitski 1995). A waxing flow results if the sediment concentration is great enough to cause the river plume to plunge during a time of increasing river discharge. Instead of eroding during this accelerating phase, hyperpycnal flows can be depositional because the magnitude of spatial deceleration can be large (i.e., the flow is strongly "depletive"; Kneller 1995) in comparison to the temporal acceleration. A hyperpycnal flow tends to be depletive because of entrainment of ambient seawater, deposition of sediment, lateral spreading, and loss of momentum at the plunge point (e.g., McLeod et al. 1999). Deposits from inferred hyperpycnal flows that exhibit reverse-tonormally graded deposits have been observed in cores from the Var River, France (Mulder et al. 2001a; Mulder et al. 2001b) and from the central Japan Sea (Nakajima 2006).

In contrast, surge-type turbidity currents generated from slumps are strongly waning because the flow velocities are greatest in the heads of the currents, and are reduced in the bodies and tails of the flows (Middleton and Southard 1984). Waxing flow occurs only at the very front of the turbidity current, and thus is extremely short lived. These flows are thought to erode during a nearly instantaneous waxing phase and then deposit as the flow wanes, creating a normally graded deposit with a vertical succession of bedforms that indicate decreasing velocity with time (i.e., Bouma sequence).

Hyperpycnal river plumes are more common in lakes (e.g., Best et al. 2005; Zavala et al. 2006), since the concentration of sediment required to exceed the density of freshwater is much less than that needed to exceed the density of seawater. There is no evidence, however, to suggest that the water body was fresh or brackish at the time of 


\section{Section 84-26}

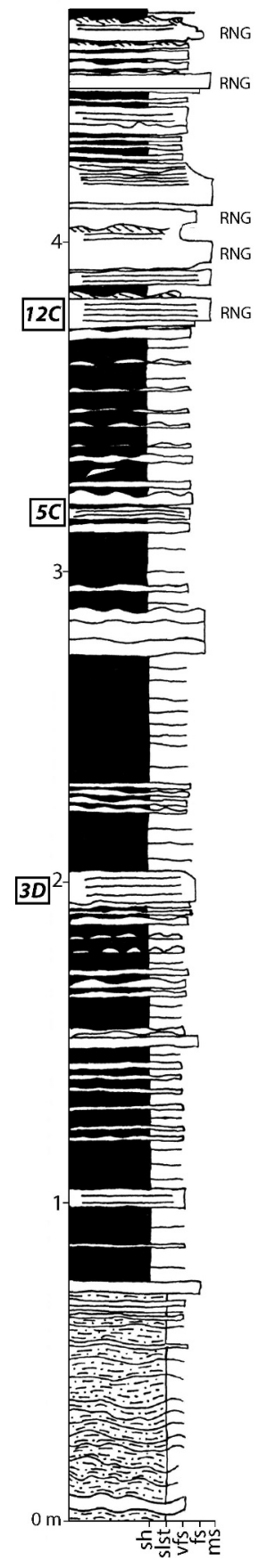

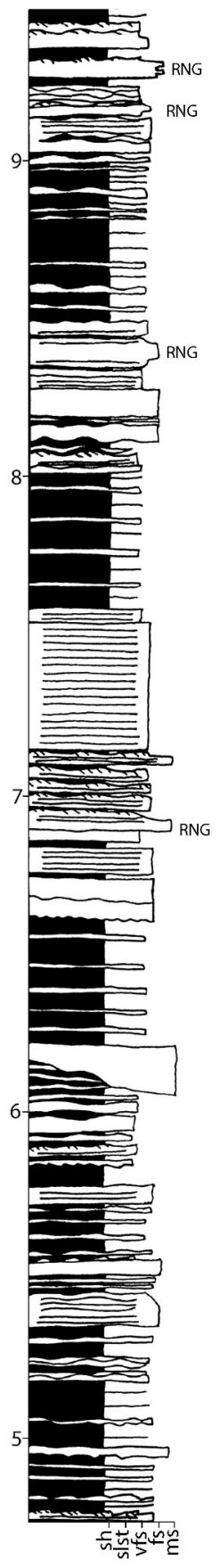

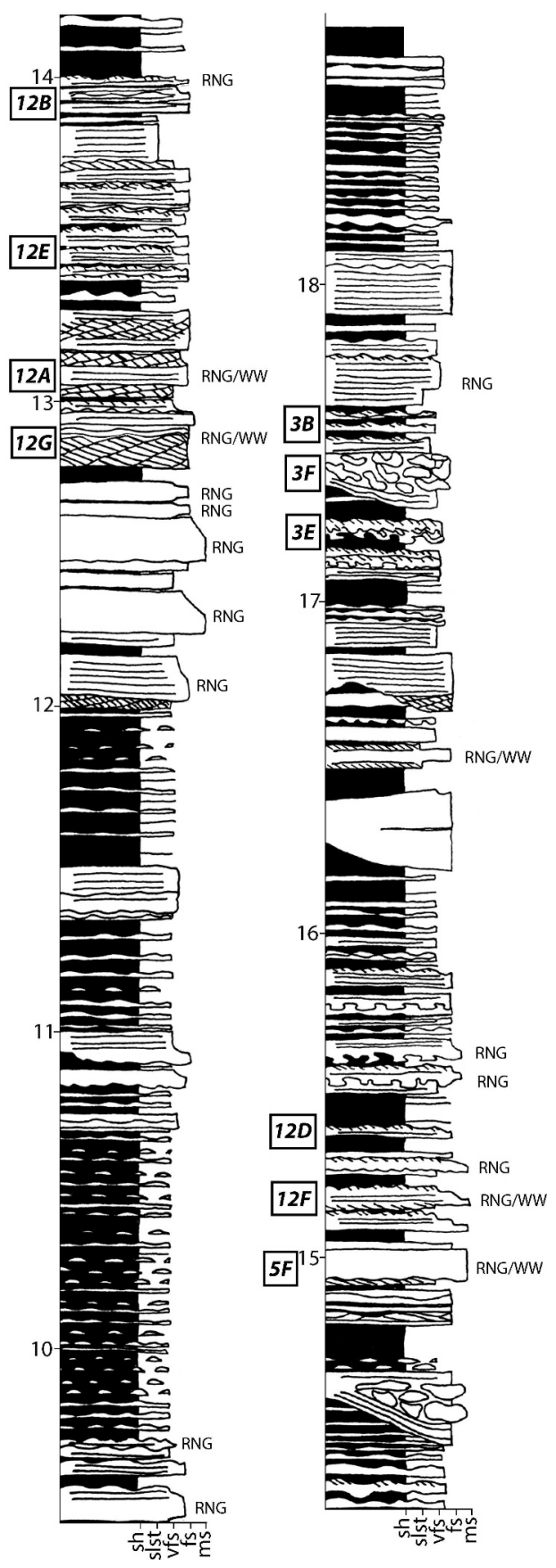

Fig. 11.-Stratigraphic section of site 84-26. See Figure 2 for location and caption to Figure 4 for legend and symbols. deposition of the Minturn Formation. In fact, well-developed limestone beds with standard Pennsylvanian open-marine fauna (brachiopods, bryozoans, echinoderms) occur within the lower part of the prodelta unit at several localities along the outcrop belt east of Bond and Copper Spur (Fig. 2).

A few beds show repeated changes in sedimentary structures and grading patterns, e.g., multiple stacked normally graded divisions (Fig. 13K). These changes typically take place throughout the thickness of a bed with no apparent bypass surfaces (e.g., Fig. 12G) and thus record relatively slow variations in the flow over the duration of an event. In some cases, however, vertical changes in grain size and bed phase are more abrupt (e.g., Fig. 13J). These features could be interpreted as the result of a series of slumps in the delta-front region during one event (e.g., retrogradational slumping). Alternatively, they might reflect pulsating flow related to temporal changes in hyperpycnal-plume discharge (Kneller and McCaffrey 2003), wave intensity, reflection of the turbidity current by obstructions (e.g., Lamb et al. 2004b), interference between flows from adjacent sources, or velocity pulsing developed within the current itself (Best et al. 2005). Such repeated fluctuations have been noted in hyperpycnites from both deep-sea cores (Nakajima 2006) and Cretaceous lacustrine deposits (Zavala et al. 2006), as well as in modern lakes (Best et al. 2005).

Whereas we interpret the reverse-to-normally graded beds and waxwane beds as potential hyperpycnal-flow deposits, we note that at distal 


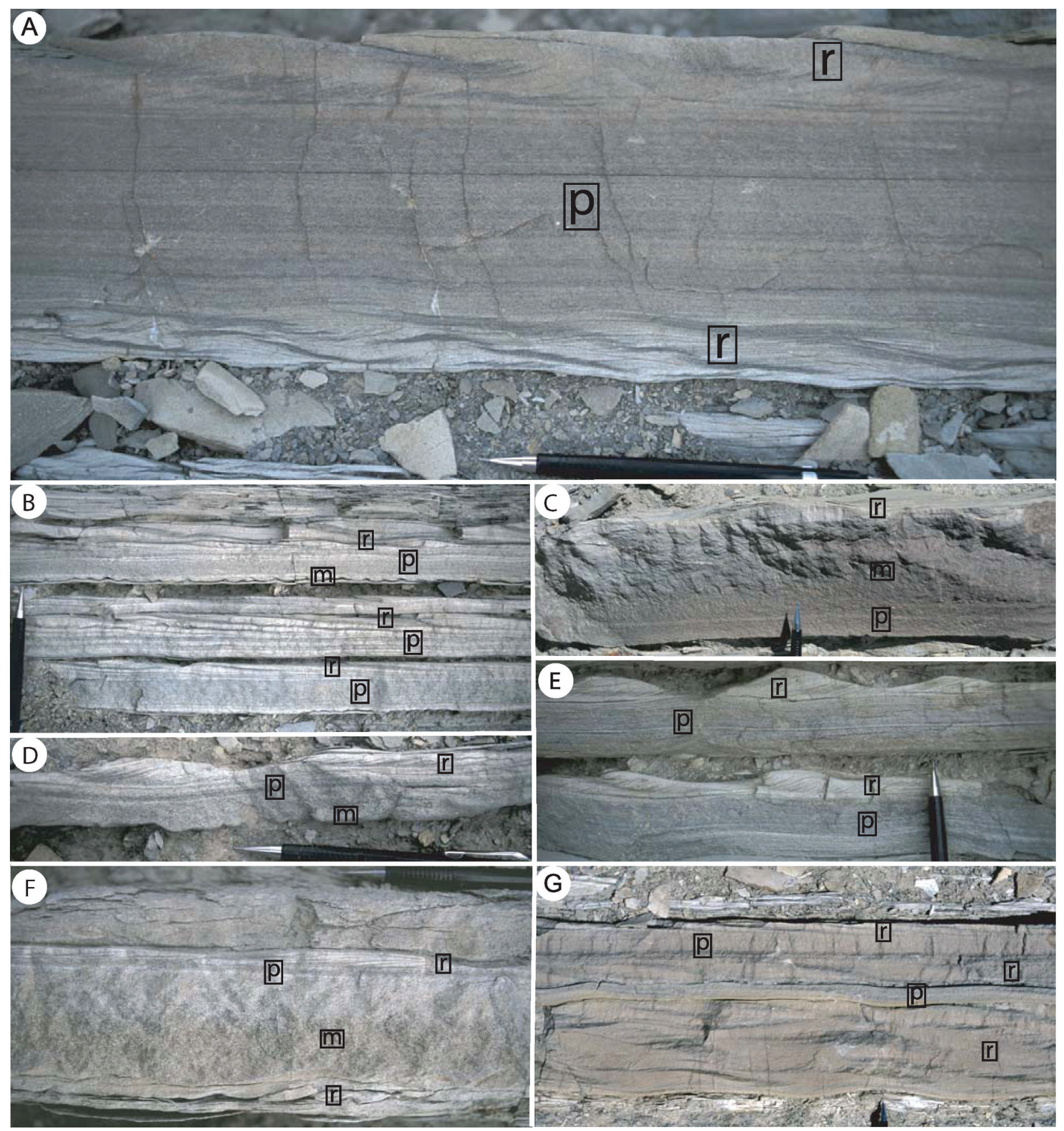

FIG. 12.-Vertical stratification and grading sequences in sandstone beds at section 84-26. The following sequences are described from the bottom to the top of each bed. Pencil for scale is $14 \mathrm{~cm}$ long and tip is $2 \mathrm{~cm}$ long. A-E show reverse-to-normally graded beds. A) Very-fine sandstone ripples (r), parallel-laminated fine sandstone (p), and very fine-sandstone ripples (r) at $12.99 \mathrm{~m}$. B) Three event beds above $13.88 \mathrm{~m}$, each of which record different flow histories. The bottom bed is reverse-tonormally graded with massive very fine sandstone at the base, parallel-laminated fine sandstone above, and finally rippled very fine sandstone at the top. The middle bed contains parallel lamination at base and top and ripples in center. The top bed, which is also reverse-to-normally graded, contains ripples, then parallel lamination, followed by more ripples. C) Bed at $3.73 \mathrm{~m}$ with parallel-laminated fine sandstone (p); massive graded division of medium to fine sandstone (m); and very fine sandstone with combined-flow ripples (r). D) Normally graded bed with classic Bouma sequence of massive to parallel-laminated to ripple-laminated divisions at $15.4 \mathrm{~m}$. E) Two normally graded beds above $13.46 \mathrm{~m}$ with parallel lamination (p) and overlying ripples (r). F) Rippled fine sandstone (r); graded, medium to fine, massive, micaceous sandstone (m); parallel-laminated fine sandstone (p); and very-fine sandstone ripples (r) at $15.28 \mathrm{~m}$. G) Alternating climbing combined-flow-ripple stratification and planar lamination at $12.77 \mathrm{~m}$. 


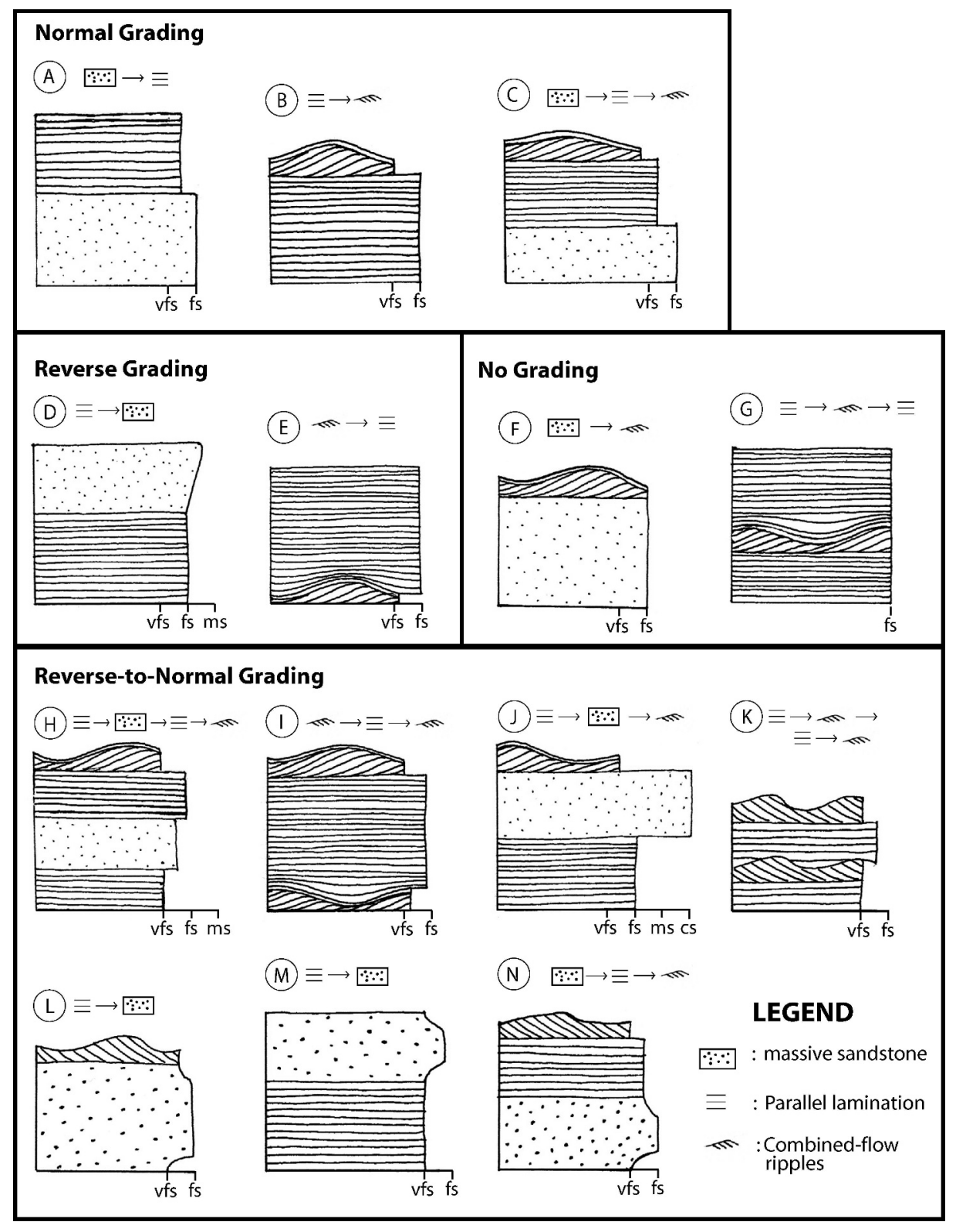

FIG. 13.-Schematic drawings of vertical stratification and grading sequences most common among the event beds at distal localities. The beds show a wide variety of grading patterns: normal grading $(\mathrm{A}-\mathrm{C})$, reverse grading (D, E), no grading (F, G), and reverse-to-normal grading $(\mathrm{H}-\mathrm{N})$. Grain sizes are very fine sand (vfs), fine sand (fs), medium sand (ms), and coarse sand (cs) as indicated by the horizontal axis. outcrop 84-26 roughly two thirds of the event beds do not contain such features (Table 1). Many of the beds are normally graded, typical of Bouma sequences. This might indicate that some beds were deposited from slump-generated surging turbidity currents. A hyperpycnal flow origin is also plausible if the sediment concentration in the flooding river plume was insufficient to form a plunging flow during the accelerating phase of the flood (e.g., Geyer et al. 2004).

\section{CONCEPTUAL MODEL}

The wide variety of grain-size grading patterns and internal sedimentary structures in the event beds of the Minturn Formation reveal the influence of both strong unidirectional and oscillatory flow. The deposition of thick HCS beds in more proximal localities and wax-wane beds in more distal localities requires careful consideration of the possible ways that waves and turbidity currents interact both in time and space. Despite the voluminous literature associated with turbidity currents, few studies have analyzed the effects of surface gravity waves on turbidity currents (e.g., Foster and Stone 1963). Wave-current boundary-layer interactions have been studied in detail (e.g., Grant and Madsen 1986); their applicability to wave-influenced turbidity currents and the resulting bed states, however, has yet to be explored. In the following section, we take a simplified approach and formulate a qualitative conceptual model to describe the interactions and bedforms that might be produced by turbidity currents and waves.

Two basic types of water motions can exist under combined flow (Fig. 15), and both may have occurred at different times and places across the onshore-offshore profile. In one case, if the maximum velocity of the oscillatory flow exceeds the velocity of unidirectional flow $\left(U_{w}>U_{c}\right)$, the combined flow would reverse direction during each half-wave cycle. Such oscillation-dominant combined flow, or reversing-current flow, is consistent with the deposition of large-scale HCS and combined-flow ripples, but not the unimodally oriented prod marks, flute marks, gutter casts and grooves that indicate powerful unidirectional flow (Dzulynski and Sanders 1962; Myrow and Southard 1996). Alternatively, if the unidirectional velocity exceeded the maximum orbital velocity of the 

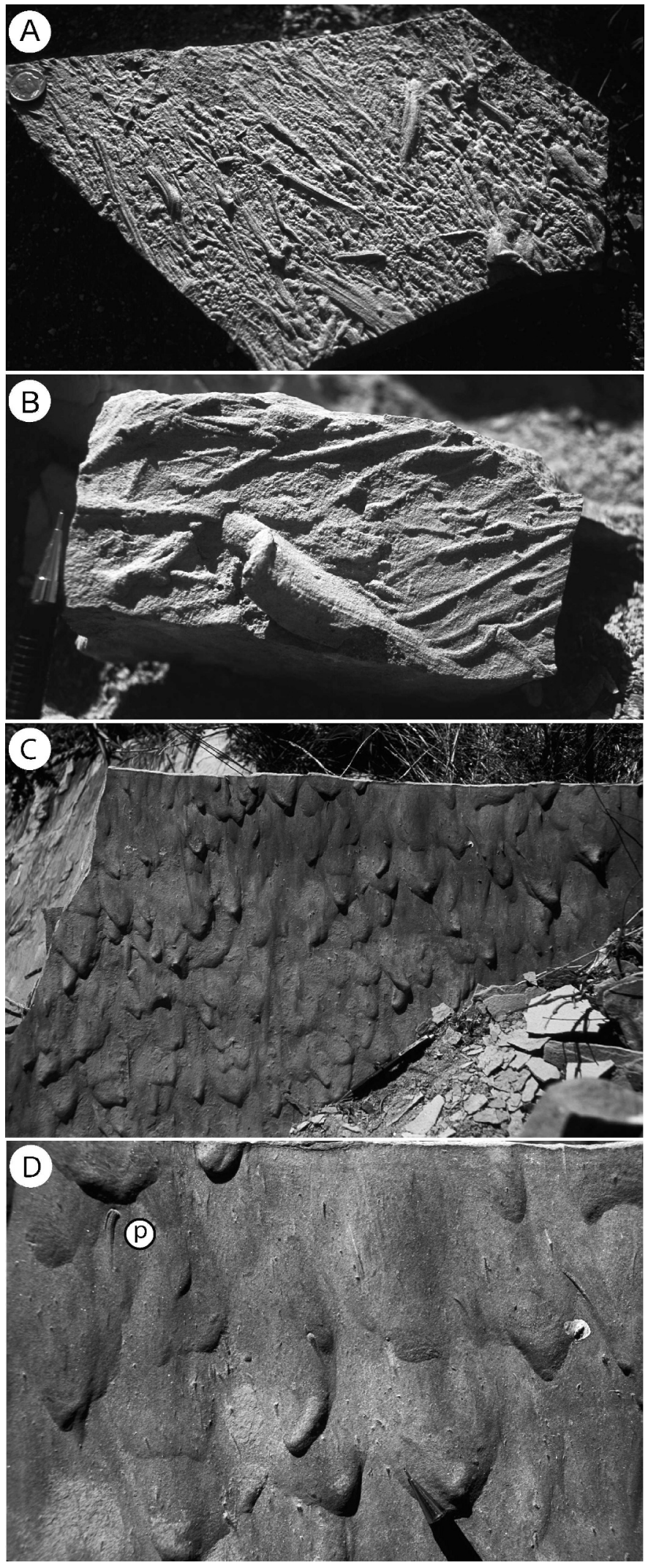

FIG. 14.- Sole Marks. A) Abundant grooves and prod marks from float (site 84-26). Dime for scale in upper left. B) Grooves and deep prod mark preserved in three dimensions. C) Flute marks with typical geometries such as V-shapes and slightly curved snouts. From float at section 87-13. D) Close-up showing flutes and prod mark (p). Pencil for scale is $14 \mathrm{~cm}$ long and tip is $2 \mathrm{~cm}$ long. oscillatory current $\left(U_{w}<U_{c}\right)$, the resulting combined flow would pulsate (i.e., accelerate and decelerate without switching direction). Pulsating flow or unidirectionally dominated combined flow is inconsistent with HCS and combined-flow ripples (Arnott and Southard 1990). To our knowledge, little is known about sole marks in pulsating flow; however, we suspect that pulsating currents produce bedforms similar to steady unidirectional flows (e.g., flutes) because the flow is always in a consistent direction (Myrow and Southard 1996).

Figure 16 illustrates a conceptual model for deposition from waveinfluenced turbidity currents. We have drawn a series of cartoons to qualitatively illustrate possible combinations of wave orbital velocity $\left(U_{w}\right)$ and current velocity $\left(U_{c}\right)$ (Fig. 16A) that could produce the observed sedimentological features of the event beds in the prodelta unit for a proximal and distal case. We arbitrarily set $U_{c}$ and $U_{w}$ to be smaller in the distal case than in the proximal case, assuming the current slows seaward due to deposition and spreading, and the near-bed wave orbital velocity weakens due to increased water depth. In nature, the temporal history of each component is likely to be more complex than our simplified example, and either component might peak before the other.

A second set of diagrams (Fig. 16B) shows the combined velocity from both the waves and currents, $U$, again for both a proximal and distal example. Approximate bedform stability fields are shown for regions of no grain motion, combined-flow ripples, HCS, and upper plane bed conditions. The stability of bedforms depends on the particle size, wave period, the total velocity of combined flow, and the relative magnitude of wave and current components (Arnott and Southard 1990; Southard 1991; Dumas et al. 2005). The bedform stability regimes in Figure 16B take into account the relative magnitude of current and wave components (e.g., we assume that HCS requires reversing-current flow: $U_{w}>U_{c}$ ), so that the path of the combined velocity curve $U$ through bedform stability space shows the type of bedforms that would be produced under depositional conditions. Unfortunately, a complete quantitative stability diagram cannot be formulated at this time because a significant range of parameter space (e.g., pulsating flow: $U_{c} \geq U_{w}$ ) remains to be explored experimentally (Arnott and Southard 1990). Quantitative boundaries can be made for some cases. For example, for very fine sand and oscillation dominated flow $\left(U_{c} \approx 0\right)$ with a wave period of $8.5 \mathrm{~s}$, incipient motion occurs at $U_{w} \approx 0.18 \mathrm{~m} / \mathrm{s}$, ripples to HCS at $U_{w} \approx 0.4 \mathrm{~m} / \mathrm{s}$, and HCS to planar bed at $U_{w} \approx 1 \mathrm{~m} / \mathrm{s}$ (Arnott and Southard 1990).

A third set of diagrams (Fig. 16C) shows the derivative of the combined velocity, namely the temporal acceleration $(\partial U / \partial t)$ as well as an estimate of the spatial deceleration $(-U \partial U / \partial x)$ assuming depletive flow. The magnitude of spatial deceleration is constant in time at any specific location in space and therefore plots as a horizontal line. We assume that the flow is nondepositional when the magnitude of temporal acceleration exceeds the magnitude of spatial deceleration (i.e., $\partial U /$ $\partial t>-U \partial U / \partial x$ ), and depositional when the opposite is true (i.e., $\partial U /$ $\partial t<-U \partial U / \partial x$ ) (e.g., Kneller 1995). This assumes that the flow is carrying its full capacity of sediment so that there is a dynamic balance between the fluxes of sediment entrainment and settling (e.g., Allen 1991; Hiscott 1994; Pratson et al. 2001; Kneller and McCaffrey 2003). Deceleration of the flow therefore decreases the entrainment of sediment from the bed, which results in deposition. During deposition, grading is inverse if the temporal acceleration is positive and normal when the temporal acceleration is negative.

Given the above assumptions, one can produce an expected temporal sequence of bed morphology and grading at a specific location on the seabed, which would be expressed as a vertical deposition sequence. For the proximal case, during time period $t_{1}$ no deposition occurs and, if the threshold for entrainment of the muddy seabed is surpassed, erosion by wave-dominated (reversing current) flow produces bidirectional sole marks (Fig. 16D). During $t_{2}$ erosion continues (or begins), possibly removing evidence of earlier scour if it existed, but this time by current- 


\section{Pulsating flow}

\section{Wave motion}

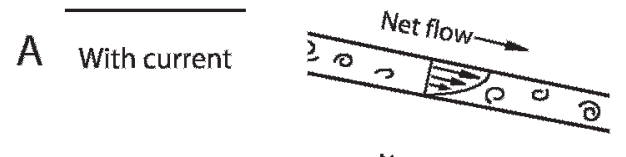

B Against current

C With current
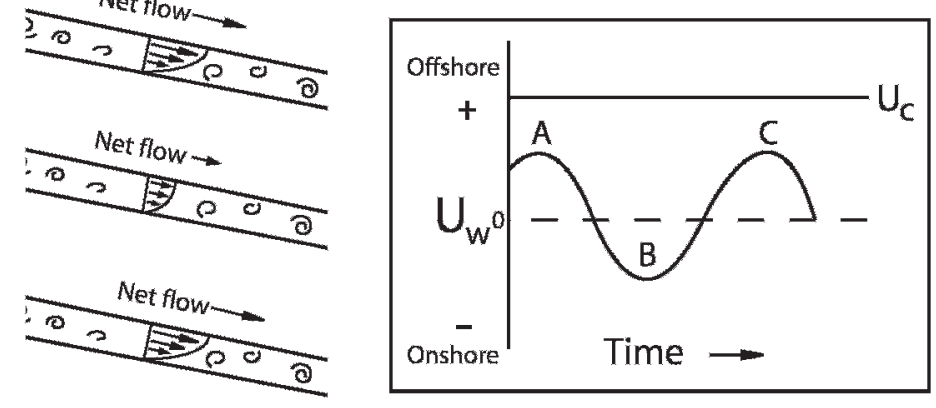

\section{Reversing-current flow}

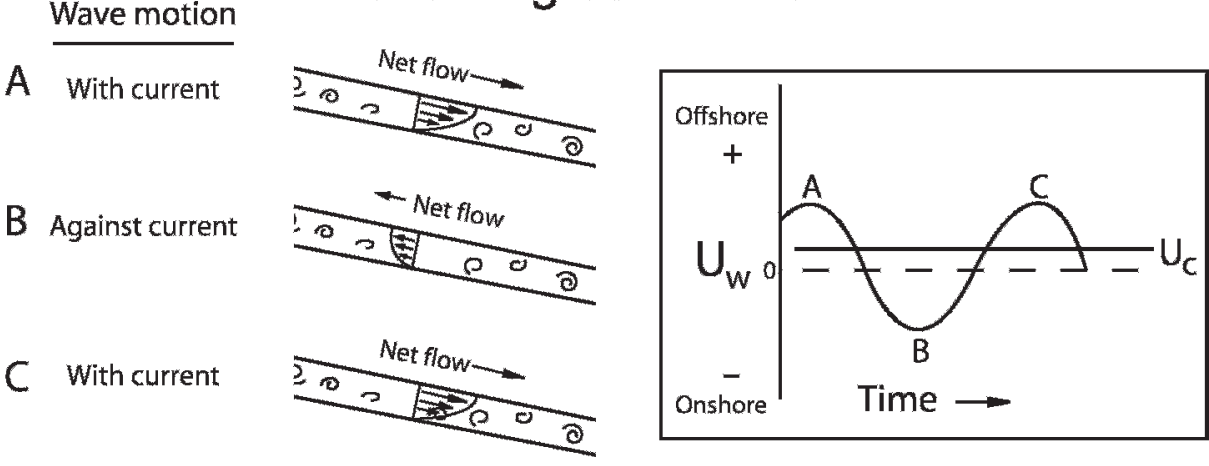

Fig. 15.-Two kinds of combined-flow currents produced under different intensities of the two components of flow. Pulsating currents occur when the wave orbital velocity $\left(U_{w}\right)$ is less than the unidirectional current velocity $\left(U_{c}\right)$. Thus, the combined flow is always in the downstream direction but at varying speeds. Reversing currents occur when the wave orbital velocity $\left(U_{w}\right)$ is greater than the unidirectional current velocity $\left(U_{c}\right)$. In this case flow reverses direction during each wave orbital cycle. The temporal histories of velocity for each component are shown on the plots on the right, and $\mathrm{A}$, $\mathrm{B}$, and $\mathrm{C}$ correspond with the cartoons illustrating flow on the left. dominated combined flow (pulsating flow), which results in flutes or unidirectionally oriented prod marks. During $t_{3}$ deposition occurs, as the magnitude of spatial deceleration now exceeds the temporal acceleration. Grading during $t_{3}$ would initially be inverse, then switching to normal, as the temporal acceleration transitions from positive to negative. Normal grading would persist through $t_{5}$. The resulting deposit consists of planar lamination for $t_{3}$, HCS during $t_{4}$, and finally combined flow ripples during $t_{5}$. At the end of $t_{5}$, deposition ceases as the velocity drops below the threshold for sediment motion.

For the distal case, erosion occurs similar to the proximal case for time periods $t_{1}$ and $t_{2}$ if the threshold for erosion of the muddy seabed is surpassed. During deposition, the bedforms are predicted to be different for the distal case compared to the proximal case because the velocity curves track differently through bedform stability space (Fig. 16B). Deposition during $t_{3}$ results in climbing combined-flow-ripple lamination with inverse grading. During $t_{4}$, planar lamination is deposited, first with inverse grading then normal grading as the temporal acceleration transitions from positive to negative. Finally, climbing combined-flowripple stratification with normal grading is deposited during $t_{5}$. The combined flow ripples might be more symmetric during wave-dominated flow early in $t_{5}$ and more asymmetric during current-dominated flow later in $t_{5}$, although only a small current velocity relative to the wave orbital velocity is needed to form asymmetric combined-flow ripples (Arnott and Southard 1990). This scenario, therefore, shows one possible explanation for deposition of beds with flutes and HCS in proximal locations, and wax-wane beds in distal locations by a single turbidity current event (Fig. 16D).

Massive bedding was not explored in the conceptual model. Presumably it can happen any time the magnitude of total deceleration is large enough that the resulting high rate of deposition suppresses traction (Kneller and Branney 1995; Arnott and Hand 1989).

\section{CONCLUSIONS}

Sandstone event beds from a shale-dominated prodelta unit of the Minturn Formation were deposited from nearshore-generated turbidity currents influenced by storm waves. Differences between outcrops in grain sizes, vertical stratification sequences, and bed thicknesses are attributed to the spatial distribution of wave effects, the temporal history of turbidity-current flow, and the interaction of these processes. We propose that storms created powerful waves and caused flooding in the hinterland directly adjacent to the field area within the Central Colorado Basin. These floods drained high-elevation regions, and the resulting rivers charged with sediment and highland plant debris evolved into turbidity currents. In proximal regions, these turbidity currents interacted strongly with oscillatory flow from storm waves resulting in deposits with characteristics of both oscillation-dominated combined flow (e.g., HCS, quasi-parallel lamination, and combined-flow-ripple lamination) and unidirectional flow (e.g., flutes). In more distal settings, the lack of oscillatory-flow features reflects the decrease in magnitude of wave energy at the seabed due to increased water depth. Beds that record waxing and waning unidirectionally dominated flow are interpreted to result from hyperpycnal river plumes that accelerated and decelerated with river discharge during floods. The distribution of sedimentary facies allowed construction of a conceptual model of deposition from wave-influenced turbidity currents that explains the formation of proximal beds with oscillation-dominated bedforms, and distal beds with current-dominated bedforms during a single event.

\section{ACKNOWLEDGMENTS}

This project was funded by National Science Foundation Grants to Paul Myrow (EAR-0309693) at Colorado College and Jeff Parsons (EAR0309887), Department of Oceanography, University of Washington. M.P. 

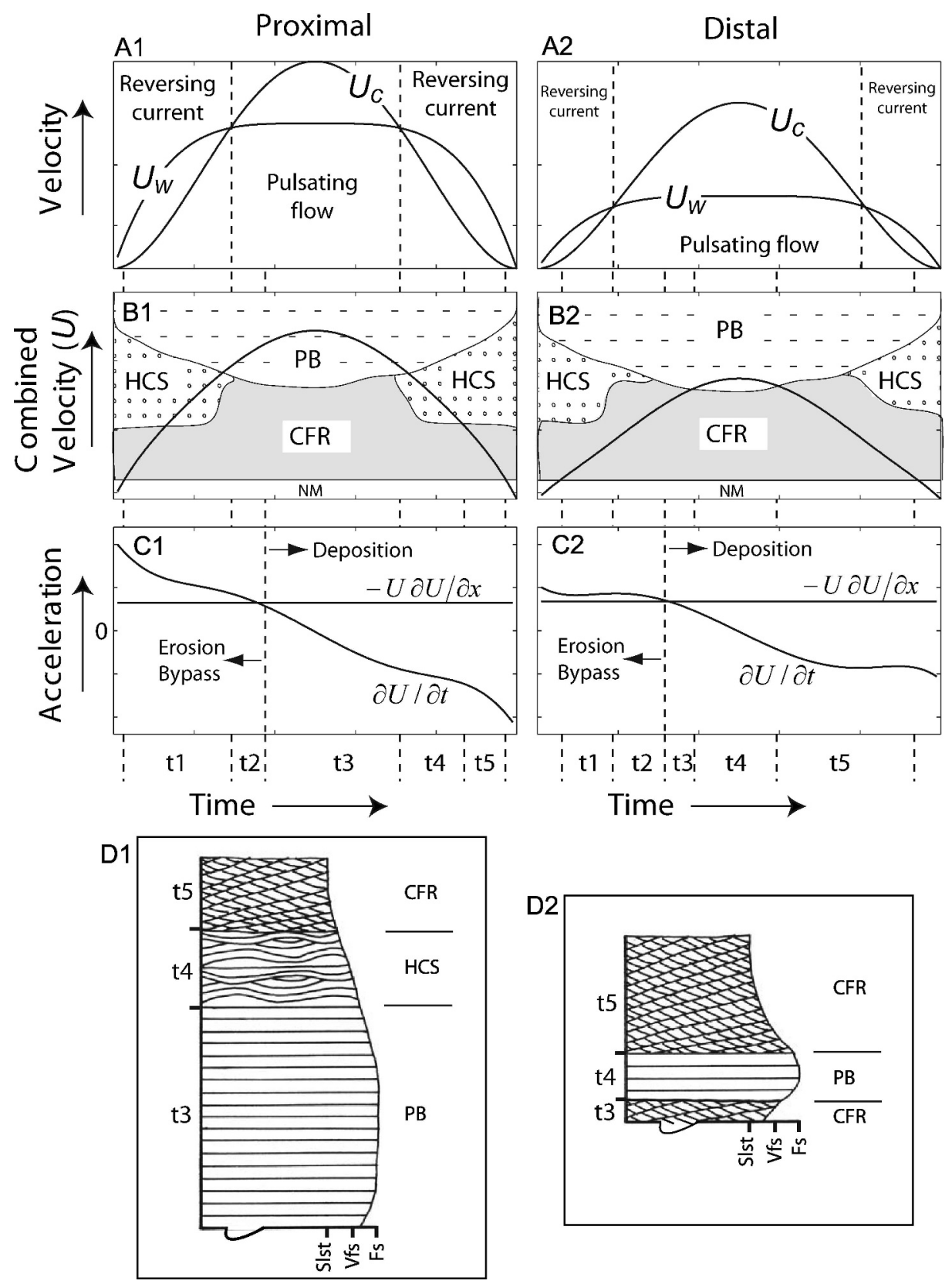

FIG. 16.-Cartoon illustrating one possible combination of wave orbital velocity $\left(U_{w}\right)$ and turbidity current velocity $\left(U_{c}\right)$ that is consistent with the observed proximal (A1) and distal (A2) event beds in the Minturn Formation. The relative magnitudes of wave and current velocities determine whether the net flow is reversing or pulsating. The combined velocity from both the waves and currents, $U=\sqrt{U_{c}^{2}+U_{w}^{2}}$, is shown for both (B1) the proximal case and (B2) the distal case. An approximate bedform stability diagram includes a zone of no grain motion (NM), combined-flow ripples (CFR), hummocky cross-stratification (HCS), and upper plane bed (PB), following Arnott and Southard (1990), Southard (1991), and Dumas et al. (2005). The intersection of the combined velocity curve and the bedform stability field at time $t$ determines the form of the bed at that time, if the flow is depositional. C) The temporal acceleration $(\partial U /$ $\partial t$ ) is shown along with an arbitrary line representing spatially decelerating or depletive flow $(-U \partial U / \partial x)$, which is constant in time at a specific location on the seabed. Inverse grading should be produced if the temporal acceleration is positive and the flow is depositional. Normal grading results when the temporal acceleration is negative. Stratification is preserved when $\partial U /$ $\partial t<-U \partial U / \partial x$. D) Sketches of representative vertical stratification sequences that correspond with the proximal and distal flow histories above. The thickness of the distal bed was arbitrarily set to one-half that of the proximal bed.
Lamb thanks Jeff Parsons for financial support and advisement during the course of this study. We also thank reviewers Tom Hickson, Piret PlinkBjörklund, and Takeshi Nakajima for their suggestions on a previous draft. Thanks to Philip Allen, Kyle Straub, Peter Talling, and John Southard for reviewing this manuscript.

\section{REFERENCES}

Aigner, T., 1982, Calcareous tempestites: Storm dominated stratification in Upper Muschelkalk Limestones (Middle Trias, SW Germany), in Einsele, G., and Seilacher, A., eds., Cyclic and Event Stratification: Berlin, Springer-Verlag, p. 180-198. Aigner, T., 1985. Storm Depositional Systems: New York, Springer-Verlag, Lecture Notes in Earth Sciences, v. 3, 174 p.

Akiyama, J., and Stefan, H.G., 1984, Plunging Flow into a Reservoir-Theory: Journal of Hydraulic Engineering, v. 110, p. 484499.

Allen, J.R.L., 1991, The Bouma Division-A and the possible duration of turbidity currents: Journal of Sedimentary Petrology, v. 61, p. 291-295.
Arnold, C.A., 1941, Some Paleozoic plants from central Colorado and their stratigraphic significance: University of Michigan, Contributions to the Museum of Paleontology, v. 6, p. 59-70

ARnotT, R.W., 1993, Quasi-planar-laminated sandstone beds of the Lower Cretaceous Bootlegger Member, north-central Montana; evidence of combined-flow sedimentation: Journal of Sedimentary Petrology, v. 63, p. 488-494.

ARNotT, R.W.C., AND HAND, B.M., 1989, Bedforms, primary structures and grain fabric in the presence of suspended sediment rain: Journal of Sedimentary Petrology, v. 59, p. $1062-1069$

ArnotT, R.W., AND Southard, J.B., 1990, Exploratory flow-duct experiments on combined-flow bed configurations, and some implications for interpreting stormevent stratification: Journal of Sedimentary Petrology, v. 60, p. 211-219.

Best, J.L., Kostaschuk, R.A., Peakall, J., Villard, P.V., and Franklin, M., 2005, Whole flow field dynamics and velocity pulsing within natural sediment-laden underflows: Geology, v. 33, p. 765-768.

Brenchley, P.J., 1985, Storm influenced sandstone beds: Modern Geology, v. 9, p. 369-396.

Crowell, J.C., 1978, Gondwanan glaciation, cyclothems, continental positioning, and climate change: American Journal of Science, v. 278, p. 1345-1372. 
Dadson, S., Hovius, N., Pegg, S., Dade, W.B., Horng, M.J., and Chen, H., 2005, Hyperpycnal river flows from an active mountain belt: Journal of Geophysical Research, v. 101, doi: 10.1029/2004JF000244.

Devoto, R.H., 1980, Pennsylvanian stratigraphy and history of Colorado, in Kent, H.C., and Porter, K.W., eds., Colorado Geology: Rocky Mountain Association of Geologists, 1980 Symposium, p. 37-50.

Donner, H.F., 1949, Geology of the McCoy area, Eagle and Routt Counties, Colorado: Geological Society of America, Bulletin, v. 60, p. 1215-1248.

DotT, R.H., AND Bourgeols, J., 1982, Hummocky stratification: significance of its variable bedding sequences: Geological Society of America, Bulletin, v. 93, p. 663-680.

DuKE, W.L., 1990, Geostrophic circulation or shallow marine turbidity currents? The dilemma of paleoflow patterns in storm-influenced prograding shoreline systems: Journal of Sedimentary Petrology, v. 60, p. 870-883.

Duke, W.L., Arnott, R.W.C., And Cheel, R.J., 1991, Shelf sandstones and hummocky cross-stratification: new insights on a stormy debate: Geology, v. 19, p. 625-628.

Dumas, S., Arnott, R.W.C., and Southard, J.B., 2005, Experiments on oscillatoryflow and combined-flow bed forms: implications for interpreting parts of the shallowmarine sedimentary record: Journal of Sedimentary Research, v. 75, p. 501-513.

Dzulynski, S., and Sanders, J.E., 1962, Current marks on firm mud bottoms: Connecticut Academy of Arts and Sciences, Transactions, p. 57-96.

Ericksen, M.C., and Slingerland, R., 1990, Numerical simulations of tidal and winddriven circulation in the Cretaceous Interior Seaway of North America: Geological Society of America, Bulletin, v. 102, p. 1499-1516.

Felix, M., Peakall, J., And McCaffrey, W.D., 2006, Relative importance of processes that govern the generation of particulate hyperpycnal flows: Journal of Sedimentary Research, v. 76, p. 1-6.

Foster, D.N., And Stone, D.M., 1963. Ocean Disposal of Ash: The University of New South Wales, Water Research Laboratory, Report 65, 130 p.

GeYer, W.R., Hill, P.S., And Kineke, G.C., 2004, The transport, transformation and dispersal of sediment by buoyant coastal flows: Continental Shelf Research, v. 24, p. 927-949.

Grant, W.D., And Madsen, O.S., 1986, The continental-shelf bottom boundary-layer: Annual Review of Fluid Mechanics, v. 18, p. 265-305.

Hamblin, A.P., and Walker, R.G., 1979, Storm-dominated shallow marine deposits: the Fernie-Kootenany (Jurassic) transition, southern Rocky Mountains: Canadian Journal of Earth Sciences, v. 16, p. 1673-1690.

HANDFORD, C.R., 1986, Facies and bedding sequences in shelf-storm-deposited carbonates-Fayetteville Shale and Pitkin Limestone (Mississippian), Arkansas: Journal of Sedimentary Petrology, v. 56, p. 123-137.

Harms, J.C., Southard, J.B., Spearing, D.R., and Walker, R.G., 1975. Depositional Environments as Interpreted from Primary Sedimentary Structures and Stratification Sequences: SEPM, Short Course Notes 2, $161 \mathrm{p}$.

Higgs, R., 1991, The Bude Formation (lower Westphalian), SW England: siliciclastic shelf sedimentation in a large equatorial lake: Sedimentology, v. 38, p. 445-469.

Hicks, D.M., Gomez, B., and Trustrum, N.A., 2004, Event suspended sediment characteristics and the generation of hyperpycnal plumes at river mouths: East Coast Continental Margin, North Island, New Zealand: Journal of Geology, v. 112, p. 471-485.

Hiscott, R.N., 1994, Loss of capacity, not competence, as the fundamental process governing deposition from turbidity currents: Journal of Sedimentary Research, v. 64, p. 209-214.

Houck, K.J., 1993. Sedimentology and stratigraphy of the middle Minturn Formation (Pennsylvanian), McCoy Area, Eagle and Routt counties, Colorado [Unpublished Ph.D. thesis]: University of Colorado, $262 \mathrm{p}$.

Houck, K.J., 1997, Effects of sedimentation, tectonics, and glacio-eustasy on depositional sequences, Pennsylvanian Minturn Formation, north-central Colorado: American Association of Petroleum Geologists, Bulletin, v. 81, p. 1510-1533.

Hoy, R.G., AND RidGwAY, K.D., 2002, Syndepositional thrust-related deformation and sedimentation in an Ancestral Rocky Mountains Basin, Central Colorado Trough, Colorado, USA: Geological Society of America, Bulletin, v. 114, p. 804-828.

Hoy, R.G., AND RidGWAY, K.D., 2003, Sedimentology and sequence stratigraphy of fandelta and river-delta deposystems, Pennsylvanian Minturn Formation, Colorado: American Association of Petroleum Geologists, Bulletin, v. 87, p. 1169-1191.

Johnson, K.S., Paull, C.K., Barry, J.P., And Chavez, F.P., 2001, A decadal record of underflows from a coastal river into the deep sea: Geology, v. 29, p. 1019-1022.

Johnson, S.Y., Chan, M.A., And Konopka, E.A., 1992. Pennsylvanian and Early Permian paleogeography of the Uinta-Piceance basin region, northwestern Colorado and northeastern Utah: U.S. Geological Survey, Bulletin 1787-CC, 35 p.

Kassem, A., And Imran, J., 2001, Simulation of turbid underflows generated by the plunging of a river: Geology, v. 29, p. 655-658.

Kineke, G.C., Woolfe, K.J., Kuehl, S.A., Milliman, J.D., Dellapenna, T.M., and Purdon, R.G., 2000, Sediment export from the Sepik River, Papua New Guinea: evidence for a divergent sediment plume: Continental Shelf Research, v. 20, p. 2239-2266.

KNELleR, B., 1995, Beyond the turbidite paradigm: physical models for deposition of turbidites and their implications for reservoir prediction, in Hartley, A.J., and Prosser, D.J., eds., Characterization of Deep Marine Clastic Systems: Geological Society Special Publication 94, p. 31-49.

KNELler, B.C., AND BranNEY, M.J., 1995, Sustained high-density turbidity currents and the deposition of thick massive sands: Sedimentology, v. 42, p. 607-616.
Kneller, B., And McCaffrey, W., 2003, The interpretation of vertical sequences in turbidite beds: the influence of longitudinal flow structure: Journal of Sedimentary Research, v. 73, p. 706-713.

Lamb, M.P., D'Asaro, E., And Parsons, J.D., 2004a, Turbulent structure of high-density suspensions formed under waves: Journal of Geophysical Research, v. 109, C12026 p, doi: 10.1029/2004JV002355.

Lamb, M.P., Hickson, T., Marr, J.G., Sheets, B., Paola, C., and Parker, G., 2004b, Surging vs. continuous turbidity currents: flow dynamics and deposits in an experimental intraslope minibasin: Journal of Sedimentary Research, v. 74, p. $148-155$.

Leckie, D.A., AND Walker, R.G., 1982, Storm-dominated and tide-dominated shorelines in Cretaceous Moosebar-Lower Gates Interval-Outcrop equivalents of deep basin gas trap in western Canada-Reply: American Association of Petroleum Geologists, Bulletin, v. 66, p. 2683-2684.

Lindsey, D.A., Clark, R.F., and Soulliere, S.J., 1986, Minturn and Sangre de Cristo formations of southern Colorado: a prograding fan delta and alluvial fan sequence shed from the Ancestral Rocky Mountains, in Peterson, J.A., ed., Paleotectonics and Sedimentation in the Rocky Mountain region, United States: American Association of Petroleum Geologists, Memoir 41, p. 541-561.

Mallory, W.W., 1972, Regional synthesis of the Pennsylvanian System, in Mallory, W.W., ed., Geologic Atlas of the Rocky Mountain Region: Rocky Mountain Association of Geologists, p. 11-127.

McLeod, P., CARey, S., and Sparks, R.S.J., 1999, Behavior of particle-laden flows into the ocean: experimental simulation and geological implications: Sedimentology, v. 46, p. $523-536$

Middleton, G.V., and Southard, J.B., 1984. Mechanics of Sediment Movement: SEPM, Short Course 3, Second Edition, $401 \mathrm{p}$.

Mohrig, D., And Marr, J.G., 2003, Constraining the efficiency of turbidity current generation from submarine debris flows and slides using laboratory experiments: Marine and Petroleum Geology, v. 20, p. 883-899.

Mulder, T., AND SyvitSKi, J.P.M., 1995, Turbidity currents generated at river mouths during exceptional discharges to the world oceans: Journal of Geology, v. 103, p. 285-299.

Mulder, T., Migeon, S., Savoye, B., and Faugeres, J.C., 2001a, Inversely graded turbidite sequences in the deep Mediterranean: a record of deposits from floodgenerated turbidity currents?: Geo-Marine Letters, v. 21, p. 86-93.

Mulder, T., Migeon, S., Savoye, B., and Jouanneau, J.M., 2001b, Twentieth century floods recorded in the deep Mediterranean sediments: Geology, v. 29, p. 1011-1014

Mulder, T., Syvitski, J.P.M., Migeon, S., Faugeres, J.C., And Savoye, B., 2003, Marine hyperpycnal flows: initiation, behavior and related deposits. A review: Marine and Petroleum Geology, v. 20, p. 861-882.

Myrow, P.M., And Southard, J.B., 1991, Combined-flow model for vertical stratification sequences in shallow marine storm-deposited beds: Journal of Sedimentary Petrology, v. 61, p. 202-210.

Mrrow, P.M., And Southard, J.B., 1996, Tempestite deposition: Journal of Sedimentary Research, v. 66, p. 875-887.

Myrow, P.M., Fischer, W., AND Goodge, J.W., 2002, Wave-modified turbidites: combined-flow shoreline and shelf deposits, Cambrian, Antarctica: Journal of Sedimentary Research, v. 72, p. 641-656.

Myrow, P.M., Lukens, C., Lamb, M.P., Houck, K., And Strauss, J., 2008, Dynamics of a transgressive prodeltaic system: implications for geography and climate within a Pennsylvanian intracratonic basin, Colorado, U.S.A.: Journal of Sedimentary Research, v. 78, in press.

Nakajima, T., 2006, Hyperpycnites deposited $700 \mathrm{~km}$ away from river mouths in the central Japan Sea: Journal of Sedimentary Research, v. 76, p. 60-73

Ogston, A.S., And Sternberg, R.W., 1999, Sediment-transport events on the northern California continental shelf: Marine Geology, v. 154, p. 69-82.

Pantin, H.M., 1979, Interaction between velocity and effective density in turbidity flow; phase-plane analysis, with criteria for autosuspension: Marine Geology, v. 31, p. 59-99.

PARKER, G., 1982, Conditions for the catastrophically erosive turbidity currents: Marine Geology, v. 46, p. 307-327.

Parsons, J.D., Bush, J.W.M., And Syvitski, J.P.M., 2001, Hyperpycnal plume formation from riverine outflows with small sediment concentrations: Sedimentology, v. 48, p. $465-478$

Pattison, S.A.J., 2005, Storm-influenced prodelta turbidite complex in the lower Kenilworth Member at Hatch Mesa, Book Cliffs, Utah, U.S.A.: implications for shallow marine facies models: Journal of Sedimentary Research, v. 75, p. $420-439$.

Pederson, G.K., 1985, Thin, fine-grained storm layers in a muddy shelf sequence: an example from the Lower Jurassic in the Stenlille 1 well, Denmark: Geological Society of London, Journal, v. 142, p. 357-374.

Plink-Björklund, P., And Steel, R.J., 2004, Initiation of turbidity currents: outcrop evidence for Eocene hyperpycnal flow turbidites: Sedimentary Geology, v. 165, p. $29-52$.

Pratson, L.F., Imran, J., Hutton, E.W.H., Parker, G., and Syvitski, J.P.M., 2001, BANG1D: a one-dimensional, Lagrangian model of subaqueous turbid surges: Computers \& Geosciences, v. 27, p. 701-716.

Ross, C.A., And Ross, J.R.P., 1987, Late Paleozoic sea levels and depositional sequences, in Ross, C.A., and Haman, D., eds., Timing and Depositional History of Eustatic Sequences: Constraints on Seismic Stratigraphy: Cushman Foundation for Foraminiferal Research, Special Publication 24, p. 137-149. 
SchenK, C.J., 1986. Turbidites in the lower part of the Eagle Valley Evaporite, Eagle County, Colorado, and implications for Desmonian paleogeography: Rocky Mountain Association of Geologists, 1986 Symposium, p. 123-128.

Southard, J.B., 1991, Experimental determination of bed-form stability: Annual Review of Earth and Planetary Sciences, v. 19, p. 423-455.

Southard, J.B., Lambie, J.M., Federico, D.C., Pile, H.T., and Weidman, C.R., 1990 Experiments on bed configurations in fine sands under bidirectional purely oscillatory flow, and the origin of hummocky cross-stratification: Journal of Sedimentary Petrology, v. 60, p. $1-17$.

Stevens, C.H., 1958. Stratigraphy and paleontology of the McCoy, Colorado, Area [Unpublished M.A. thesis]: University of Colorado, $242 \mathrm{p}$.

SwIFT, D.J.P., 1985, Response of the shelf floor to flow, in Tillman, R.W., Swift, D.J.P., and Walker, R.G., eds., Shelf Sands and Sandstone Reservoirs: SEPM, Short Course Notes, no. 13, p. 135-241.

Swift, D.J.P., Gregory, H., And Vincent, C.E., 1986, Fluid processes and sea-floor response on a modern storm-dominated shelf: middle Atlantic Shelf of North America. Part 1: The storm-current regime, in Knight, R.J., and McLean, J.R., eds., Shelf Sands and Sandstones: Canadian Society of Petroleum Geologists, Memoir 2, p. 99-119.

Traykovski, P., Geyer, W.R., Irish, J.D., And Lynch, J.F., 2000, The role of waveinduced density-driven fluid mud flows for cross-shelf transport on the Eel River continental shelf: Continental Shelf Research, v. 20, p. 2113-2140.

Trowbridge, J.H., And Kineke, G.C., 1994, Structure and dynamics of fluid muds on the Amazon continental shelf: Journal of Geophysical Research, v. 99, p. 865 874.

Tweto, O., 1949, Stratigraphy of the Pando area, Eagle County, Colorado: Colorado Scientific Society, Proceedings, v. 15, p. 149-235.

Tweto, O., And Lovering, T.S., 1977. Geology of the Minturn 15-minute quadrangle, Eagle and Summit Counties, CO: U.S. Geological Survey, Professional Paper 956, $96 \mathrm{p}$. van den Berg, J.H., van Gelder, A., and Mastbergen, D.R., 2002, The importance of breaching as a mechanism of subaqueous slope failure in fine sand: Sedimentology, v. 49 , p. $81-95$.

Walker, R.G., 1984, Shelf and shallow marine sands, in Walker, R.G., ed., Facies Models: Geoscience Canada, Reprint Series 1, p. 141-170.

Warrick, J.A., AND Milliman, J.D., 2003, Hyperpycnal sediment discharge from semiarid southern California rivers: Implications for coastal sediment budgets: Geology, v. 31, p. 781-784.

Wright, L.D., AND Friedrichs, C.T., 2006, Gravity-driven sediment transport on continental shelves: A status report: Continental Shelf Research, v. 26, p. 2092-2107.

Wright, M.E., AND Walker, R.G., 1982, Cardium Formation at Seebe, AlbertaStorm-transported sandstones and conglomerates: American Association of Petroleum Geologists, Bulletin, v. 66, p. 644-645.

Wright, L.D. Yang, Z S., Bornhold, B.D., Keller, G.H., Prior, D. B., and Wiseman, W.J, JR, 1986, Hyperpycnal plumes and plume fronts over the Huanghe (Yellow River) delta front: Geo-Marine Letters, v. 6, p. 107-113.

Wright, L.D., Friedrichs, C.T., Kim, S.C., AND Scully, M.E., 2001, Effects of ambient currents and waves on gravity-driven sediment transport on continental shelves: Marine Geology, v. 175, p. 25-45.

YoKoKaWA, M., 1995. Combined-flow ripples: genetic experiments and applications for geologic records: Kyushu University, Faculty of Science, Memoirs, Series D, Earth and Planetary Sciences, v. 29, p. 1-38.

Yokokawa, M., Masuda, F., And Endo, N., 1995, Sand particle movement on migrating combined-flow ripples: Journal of Sedimentary Research, v. 65, p. 40-44.

Zavala, C., Ponce, J.J., Arcuri, M., Drittanti, D., Freije, H., and Asensio, M., 2006, Ancient lacustrine hyperpycnites: a depositional model from a case study in the Rayoso Formation (Cretaceous) of west-central Argentina: Journal of Sedimentary Research, v. 76, p. 41-59.

Received 11 September 2007; accepted 17 January 2008 